Article

\title{
Amyloid-Beta Peptides and Activated Astroglia Impairs Proliferation of Nerve Growth Factor Releasing Cells In Vitro: Implication for Encapsulated Cell Biodelivery-Mediated AD Therapy
}

\author{
Sumonto Mitra ${ }^{1, *(\mathbb{D})}$, Silvia Turchetto ${ }^{2,3}$, Winant Van Os ${ }^{2,4}$, Lars U. Wahlberg ${ }^{5}$, Bengt Linderoth ${ }^{6}$, \\ Homira Behbahani ${ }^{1,7, *}$ and Maria Eriksdotter ${ }^{1,8}$
}

Citation: Mitra, S.; Turchetto, S.; Van Os, W.; Wahlberg, L.U.; Linderoth, B.; Behbahani, H.; Eriksdotter, M.

Amyloid-Beta Peptides and Activated Astroglia Impairs Proliferation of

Nerve Growth Factor Releasing Cells In Vitro: Implication for Encapsulated Cell Biodelivery-Mediated AD Therapy. Cells 2021, 10, 2834. https:// doi.org/10.3390/cells10112834

Academic Editors: Simona Capsoni and Arpad Dobolyi

Received: 17 August 2021

Accepted: 14 October 2021

Published: 21 October 2021

Publisher's Note: MDPI stays neutral with regard to jurisdictional claims in published maps and institutional affiliations.

Copyright: (c) 2021 by the authors. Licensee MDPI, Basel, Switzerland. This article is an open access article distributed under the terms and conditions of the Creative Commons Attribution (CC BY) license (https:/ / creativecommons.org/licenses/by/ $4.0 /)$.
1 Division of Clinical Geriatrics, Center for Alzheimer Research, Department of Neurobiology, Care Sciences and Society (NVS), Karolinska Institutet, 14152 Stockholm, Sweden; Maria.eriksdotter@ki.se

2 Division of Neurogeriatrics, Center for Alzheimer Research, Department of Neurobiology, Care Sciences and Society (NVS), Karolinska Institutet, 17164 Stockholm, Sweden; silvia.turchetto@uliege.be (S.T.); w.l.van.os@lic.leidenuniv.nl (W.V.O.)

3 GIGA-Stem Cells and GIGA-Neurosciences, Interdisciplinary Cluster for Applied Geno-Proteomics (GIGA-R), University of Liège, 4000 Liège, Belgium

4 Wiskunde en Natuurwetenschappen, LIC/Chemical Biology, Leiden Institute of Chemistry, 2300 RA Leiden, The Netherlands

5 Gloriana Therapeutics, Inc., Warren, Rhode Island, RI 02885, USA; LUW@GlorianaTx.com

6 Department of Clinical Neuroscience, Karolinska Institutet, 17177 Stockholm, Sweden; bengt.linderoth@gmail.com

7 Karolinska University Laboratories, Karolinska University Hospital, 18450 Stockholm, Sweden

8 Theme Aging, Karolinska University Hospital, 14186 Huddinge, Sweden

* Correspondence: sumonto.mitra@ki.se (S.M.); homira.behbahani@ki.se (H.B.); Tel.: +46-(0)7-349-675-24 (S.M.); +46-(0)70-433-20-91 (H.B.)

Abstract: Alzheimer's disease (AD) treatment is constrained due to the inability of peripherally administered therapeutic molecules to cross the blood-brain barrier. Encapsulated cell biodelivery (ECB) devices, a tissue-targeted approach for local drug release, was previously optimized for human mature nerve growth factor (hmNGF) delivery in AD patients but was found to have reduced hmNGF release over time. To understand the reason behind reduced ECB efficacy, we exposed hmNGFreleasing cells (NGC0211) in vitro to human cerebrospinal fluid (CSF) obtained from Subjective Cognitive Impairment (SCI), Lewy Body Dementia (LBD), and AD patients. Subsequently, we exposed NGC0211 cells directly to AD-related factors like amyloid- $\beta$ peptides $\left(A \beta_{40 / 42}\right)$ or activated astrocyte-conditioned medium ( $\mathrm{A} \beta_{40 / 42} / \mathrm{IL}-1 \beta / \mathrm{TNF} \alpha$-treated) and evaluated biochemical stress markers, cell death indicators, cell proliferation marker (Ki67), and hmNGF release. We found that all patients' CSF significantly reduced hmNGF release from NGC0211 cells in vitro. A $\beta_{40 / 42}$, inflammatory molecules, and activated astrocytes significantly affected NGC0211 cell proliferation without altering hmNGF release or other parameters important for essential functions of the NGC0211 cells. Long-term constant cell proliferation within the ECB device is critically important to maintain a steady cell population needed for stable mNGF release. These data show hampered proliferation of NGC0211 cells, which may lead to a decline of the NGC0211 cell population in ECBs, thereby reducing hmNGF release. Our study highlights the need for future studies to strengthen ECBmediated long-term drug delivery approaches.

Keywords: Alzheimer's disease (AD); astrocytes; amyloid beta (A $\beta)$; encapsulated cell biodelivery (ECB); nerve growth factor (NGF); drug delivery strategy optimization; inflammation

\section{Introduction}

Alzheimer's disease (AD) is associated with early loss of basal forebrain cholinergic neurons (BFCNs) function, among other pathological features including amyloid-beta $(\mathrm{A} \beta)$ 
accumulation, astroglial activation, and inflammation [1,2]. BFCNs are highly dependent on the mature form of neurotrophin-nerve growth factor (mNGF) to maintain their survival and cholinergic phenotype during development and adulthood [1,3]. Dysregulation of the mNGF biosynthesis cascade has been reported in AD, predominantly leading to the accumulation of its precursor (proNGF) [4-6]. Concomitantly, a reduced ratio of NGF receptors, Tropomyosin receptor kinase A (TrkA-the high-affinity mNGF-specific receptor) to p75 neurotrophin receptor (p75NTR-low-affinity $\mathrm{mNGF}$ receptor), has been observed in the basal forebrain during AD progression [7-9], further hampering mNGF uptake and altered downstream signaling, leading to cognitive dysfunction $[1,10]$.

Delivery of mNGF was envisioned to increase BFCN cell survival by reviving TrkA signaling present locally on cell bodies, which are still intact during the AD continuum [1]. This activation of BFCN TrkA signaling may stimulate acetylcholine production, activate cholinergic synaptic activity, re-establish cholinergic neurotransmission, and enhance innervation to the cortical and hippocampal regions crucial for cognition and memory function [11-13]. Until now, mNGF delivery in the AD patient's brain has been accomplished by various methods including direct ventricular injection, gene therapy (using viral vectors), or encapsulated cell biodelivery (ECB) [14]. The ECB device is a hollow capsular device surrounded by a semi-permeable membrane (280 kDa cut-off), which harbor genetically modified cells growing in a 3-D matrix and can be retrieved from the brain after intended durations of therapy [15]. ECB implantation facilitates local delivery of therapeutic molecules over a long time, which needs an active cell population to be present inside ECB and had been used to deliver various therapeutic molecules in different conditions, such as epilepsy [14]. The precision of the delivery and tolerability of ECB-NGF therapy have been previously reported by our group in an open-label phase $1 \mathrm{~b}$ clinical trial $[16,17]$. It was previously observed that human mature NGF (hmNGF) release from the ECB's containing the genetically modified human retinal pigment epithelial (ARPE-19) cell line were affected when they remained implanted over time and assessed following explantation from human or animal brains $[17,18]$.

It has been shown before in cases of age-related macular degeneration (AMD) that inflammatory molecules and $\mathrm{A} \beta$ peptides can impair retinal pigment epithelial (RPE) cells [19]. AD pathology is also associated with soluble inflammatory factors, cytokines, complement proteins, and $\mathrm{A} \beta$ peptides which may diffuse into the $\mathrm{ECB}$ owing to their small size (<280 kDa; ECB membrane molecular cut-off). Moreover, the surgical ECB implantation procedure may result in local tissue damage, glial activation, and capillary vessel disruption, leading to increased inflammatory conditions [20]. All these factors may potentially affect the cells present inside the ECBs, but due to technical limitations, these issues cannot be studied in vivo. Thus, using an in vitro experimental set-up, the effect of these factors on hmNGF-releasing cells needs to be investigated.

Our previous studies using the first generation of hmNGF-releasing cells (termed NGC0295) showed that these cells were physiologically under stress and are sensitive to the inflammatory molecule interleukin-1beta (IL-1 $\beta$ ), which affected hmNGF release over time [21]. To increase hmNGF release, a second generation of hmNGF-producing cells (termed NGC0211) was developed using transposon-mediated gene transfer, which

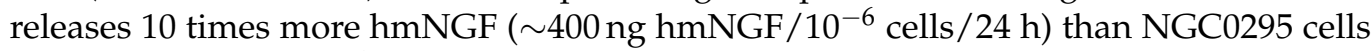
( $30 \mathrm{ng} \mathrm{hmNGF} / 10^{-6}$ cells $/ 24 \mathrm{~h}$ ) [18]. In our previous clinical trial study [17], when NGC0211 cell-containing ECBs were implanted within the human brain, we observed altered hmNGF release from the ECB devices as follows: 13 out of a total of 16 implants released some hmNGF whereas 3 implants failed to release detectable amounts of hmNGF. Among the devices that released hmNGF, eight implants released hmNGF at the same rate or higher than pre-implantation levels. To understand the reason behind this variable efficiency of hmNGF release from ECBs, we need to investigate whether the NGC0211 cell viability or activity is altered after exposure to CSF or other AD-associated molecules. In the present study, we assessed whether AD-associated factors like soluble A $\beta$ peptides $\left(\mathrm{A} \beta_{40 / 42}\right)$ may affect the hmNGF-releasing capacity of NGC0211 cells, (1) either directly by 
inducing stress and toxic effects, or (2) by activating astroglial cells to release inflammatory molecules, which, in turn, may affect NGC0211 cells.

\section{Materials and Methods}

\subsection{Plasmid Preparation and Generation of NGC0211 Cells}

Preparation of the plasmid has been described elsewhere in detail [18]. Briefly, PCRamplified HEK293 genomic DNA was cloned in pcDNA3.1(+) vector (Invitrogen, Gothenburg, Sweden), and modified to contain cytomegalovirus promoter/chimeric intron from pCI-neo (Promega, Madison, WI, USA) along with the cytomegalovirus early enhancer element/chicken beta-actin (CA) promoter sequence from pCAIB. From the resulting plas$\mathrm{mid}$, the hmNGF and neomycin resistance cassettes were excised as a single fragment and inserted into the Sleeping Beauty (SB) substrate vector pT2BH, to generate the final plasmid termed pT2.CAn.hNGF.

The human RPE cell line, ARPE-19 (ATCC, Manassas, VA, USA), was cultured in DMEM/F12 medium supplemented with GlutaMAX (Invitrogen) and 10\% fetal bovine serum (FBS) (Hyclone, Logan, UT, USA) at $37{ }^{\circ} \mathrm{C}$ and $5 \% \mathrm{CO}_{2}$. ARPE- 19 cells were co-transfected with pT2.CAn.hNGF and pCMV-SB-100X (expressing hyperactive SB transposase without antibiotic resistance element) plasmids using FuGENE (Roche, Basel, Switzerland) according to the manufacturer's protocol. Transfected cells were selected using G418 (Sigma-Aldrich, St. Louis, MO, USA) and single-cell clonal colonies were expanded. The clone NGC0211 was used for the previous human phase $1 \mathrm{~b}$ clinical trial [17], and therefore, was selected for use in the present study.

\subsection{Two-Dimensional Cell Cultures}

NGC0211 cells were cultured in complete DMEM/F12 medium containing GlutaMAX and $10 \%$ heat-inactivated $\mathrm{FBS}$ at $37{ }^{\circ} \mathrm{C}$ and $5 \% \mathrm{CO}_{2}$. Confluent (85-90\%) NGC0211 cultures were split until they were used for experiments (passage number 10-20). For splitting, cells were washed twice with phosphate-buffered saline (PBS) (Invitrogen), trypsinized using TrypLE Express Enzyme (Life Technologies, Carlsbad, CA, USA), and replated as a 1:3 ratio into T-75 flasks (Corning, New York, NY, USA) in culture medium.

For human CSF exposure (discussed in Section 2.10), NGC0211 cells were cultured in human endothelial serum-free medium (HE-SFM) (Invitrogen). The choice of medium was dictated by the necessity to avoid serum constituents from the culturing process and assess the specific contribution of CSF in modulating NGC0211 cells' response. Cells were maintained in HE-SFM for $24 \mathrm{~h}$ before initiating CSF exposure. HE-SFM media was used since NGC0211 cells do not grow well in serum-free DMEM/F12 (unpublished data).

Cortical human primary astrocytes (Cat no.1800) and all related culture medium supplements were purchased from ScienCell Research Laboratories (Carlsbad, CA, USA). Cells were initially grown and subsequently cultured on poly-L-lysine-coated T-75 flasks in astrocyte culture medium (Cat no. 1801) containing 2\% FBS (Cat no. 0010), 1\% PenicillinStreptomycin concentrate (Cat no. 0503), and 1\% of astrocyte growth supplement (Cat no. 1852), following the manufacturer's recommendations. Sub-culturing was done when cells reached $80-85 \%$ confluency in a 1:4 ratio. All cell culture experiments were completed utilizing 2 nd-5th passage number.

\subsection{A $\beta$ Peptide Preparation and Cell Culture Exposure}

$A \beta$ peptide $\left(A \beta_{40}\right.$ and $\left.A \beta_{42}\right)$ soluble oligomers were prepared as reported earlier, with minor adjustments [22]. Briefly, vials of human $A \beta_{40}$ or $A \beta_{42}$ peptides expressed in $E$. coli (rPeptides, Lelystad, The Netherlands) were incubated for $30 \mathrm{~min}$ at room temperature (RT) and then dissolved in dimethyl sulfoxide (DMSO) to obtain stock concentrations of $0.5 \mathrm{mM}$, respectively. Resulting solutions were vortexed vigorously, sonicated at $40 \mathrm{~Hz}$ (Branson 2510 bath sonicator, Sigma-Aldrich, St. Louis, MO, USA) for $10 \mathrm{~min}$, aliquoted, and stored at $-20^{\circ} \mathrm{C}$ until use. For the experiments, aliquots were thawed and diluted to working concentrations $(1,0.5,0.1,0.05 \mu \mathrm{M})$ in respective culture medium and used 
immediately for cell exposure. It has been shown previously that oligomeric $\mathrm{A} \beta$ peptides when diluted in culture medium maintain their oligomeric form at least until $70 \mathrm{~h}$ [23]. The FBS concentration in direct exposure is matched with that of the indirect exposure (explained in Section 2.4), maintaining 5\% FBS concentration during the exposure period.

\subsection{Astrocyte-Conditioned Media (ACM)}

Following trypsinization, astrocytes were plated on poly-L-lysine-coated 24-well plates $\left(7 \times 10^{4}\right.$ cells / well $)$ and left for $24 \mathrm{~h}$ to recover. Medium was thereafter changed, and adhering cells were treated with either of the following: $A \beta_{40 / 42}$ peptide $(1,0.5,0.1$, $0.05 \mu \mathrm{M})$, tumor necrosis factor alpha (TNF $\alpha, 20 \mathrm{ng} / \mathrm{mL})$, or IL-1 $\beta(2 \mathrm{ng} / \mathrm{mL})$ used here as a positive control for astrocyte activation or left unstimulated (untreated control) in a total volume of $500 \mu \mathrm{L}$. After $24 \mathrm{~h}$ of exposure, supernatant was collected and designated as astrocyte-conditioned medium (ACM). The ACMs were mixed with complete DMEM/F12 medium (50:50\% media ratio) and used to stimulate NGC-0211 cells or ECBs. Equivalent amounts of TNF $\alpha$ and IL-1 $\beta$ were used to study their direct effect on NGC0211 cells following the same experimental set-up.

\subsection{ECB Device Preparation and Treatment Exposure}

Seven-millimeter-long ECB devices were manufactured from semi-permeable ( $280 \mathrm{kDa}$ mean molecular weight cut-off) polysulfone hollow fiber membranes (Gloriana Therapeutics, Rhode Isalnd, RI, USA) threaded with a polyester terephthalate (PET) yarn matrix (Swicofil, Emmen, Switzerland). Each device was filled with $6 \mu \mathrm{L}$ of cell suspension (10,000 cells / $\mu$ L HE-SFM) by a semiautomatic custom-made cell injector system (Kineteks, Warwick, IL, USA) and sealed using a photopolymerized acrylic adhesive (Dymax, Torrington, CT, USA). Devices loaded with NGC0211 cells were maintained in $1 \mathrm{~mL}$ of HE-SFM medium at standard cell culture conditions for 2-3 weeks with weekly media replacements before initiating experimentation.

Prior to experimentation, the ECBs were incubated in complete DMEM/F12 media for 1 week. Initially, ECBs were cultured in $1 \mathrm{~mL}$ of DMEM/F12 complete medium for $4 \mathrm{~h}$, and $500 \mu \mathrm{L}$ of medium were collected as pre-exposure samples, which were kept in a $-80{ }^{\circ} \mathrm{C}$ freezer until use. ECBs were then exposed to $\mathrm{A} \beta_{40 / 42}$ peptides $(1 \mu \mathrm{M})$ or $\mathrm{ACMs}$ (astrocytes treated with $1 \mu \mathrm{M} \mathrm{A} \beta_{40 / 42}$ ) and incubated for 7 days. ECBs were then transferred to $1 \mathrm{~mL}$ of fresh complete DMEM/F12 medium, incubated for $4 \mathrm{~h}$, and once more, $500 \mu \mathrm{L}$ of medium were collected as post-exposure samples, and saved in a $-80^{\circ} \mathrm{C}$ freezer for future hmNGF ELISA analysis.

In the remaining medium along with the ECBs, $50 \mu \mathrm{L}$ of $10 \times$ alamarBlue (Invitrogen) were added to measure the total metabolic activity of the cells, mixed, and incubated for $1 \mathrm{~h}$. From each well, $100 \mu \mathrm{L}$ were drawn in triplicate, plated in a black bottom 96well plate (Corning, New York, NY, USA), and fluorescence was read at $560 \mathrm{~nm} / 590 \mathrm{~nm}$ (excitation/emission) in a spectrophotometer (Safire II Plate reader, Tecan, Männedorf, Switzerland) with a $5 \mathrm{~nm}$ bandpass filter and top read mode.

\subsection{Biochemical Measurements}

To ascertain the ability of $A \beta_{40 / 42}$ peptides or ACMs to induce cellular stress, biochemical measurements for the following parameters were performed: reactive oxygen species (ROS, $20 \mu \mathrm{M} \mathrm{H}_{2}$ DCFDA, 485/520 nm), total glutathione (GSH, $50 \mu \mathrm{M} \mathrm{mBCL}, 394 / 490 \mathrm{~nm}$ ), mitochondrial membrane potential $(\triangle \Psi \mathrm{m}, 0.2 \mu \mathrm{M}$ TMRM, $548 / 574 \mathrm{~nm})$, as well as overall metabolic activity using alamarBlue $(560 / 590 \mathrm{~nm})$. All chemicals were obtained from Invitrogen. To perform these experiments, cells $\left(1 \times 10^{4}\right.$ cells/well/100 $\left.\mu \mathrm{L}\right)$ were plated onto 96-well clear bottom black plates (Corning, New York, NY, USA) and experiments were conducted for early ( $0-1 \mathrm{~h}$ kinetics, $3 \mathrm{~h}$ endpoint) and late ( $24 \mathrm{~h}$ endpoint) time points, respectively. Measurements were taken at a constant temperature of $37^{\circ} \mathrm{C}$ using a spectrophotometer (top read mode to measure metabolic activity and bottom read mode for all other parameters). 
For kinetic measurements up to $1 \mathrm{~h}$, for ROS and GSH levels, cells were pre-incubated with $\mathrm{H}_{2}$ DCFDA or $\mathrm{mBCL}$ for 20 min followed by $\mathrm{A} \beta_{40 / 42}$ peptides or ACMs exposure in a final volume of $100 \mu \mathrm{L} /$ well. The plate was then returned to the incubator and finally $3-\mathrm{h}$ end-point data were acquired from the same plate. To measure $\Delta \Psi \mathrm{m}$ post $3 \mathrm{~h}$ of exposure, TMRM was added for the last 20 min followed by washing the cells twice with PBS and fluorescence was acquired in $100 \mu \mathrm{L}$ of PBS. Similarly, to measure metabolic activity at $3 \mathrm{~h}$, alamarBlue was added during the last $1 \mathrm{~h}$ and data was acquired. To evaluate late effects on biochemical parameters, endpoint readings were taken after $24 \mathrm{~h}$ of exposure to $\mathrm{A} \beta_{40 / 42}$ peptides or ACMs. For $\mathrm{H}_{2}$ DCFDA, mBCL, or TMRM, probes were added for the last 20 min and the fluorescence measurements were recorded as mentioned above. For metabolic activity, alamarBlue was added $1 \mathrm{~h}$ before the recording of the activity measurement by the spectrophotometer as mentioned previously.

\subsection{Immunocytochemistry and Image Analysis}

The proliferative ability of NGC0211 cells was evaluated by staining for the proliferationassociated protein Ki67. Briefly, cells $\left(0.5 \times 10^{4}\right.$ cells/well/100 $\left.\mu \mathrm{L}\right)$ were plated in a 16-well chamber slide (Lab-Tek, ThermoFisher Scientific, Gothenburg, Sweden) and exposed to various conditions. After $24 / 48 / 72 \mathrm{~h}$ of incubation, cells were washed $3 \times$ with PBS, fixed using phosphate-buffered formaldehyde 4\% (v/v) (Sigma-Aldrich, St. Louis, MO, USA) for 5 min at RT, and permeabilized using 0.2\% Triton X-100 (Sigma-Aldrich, St. Louis, MO, USA) for 15 min. Following $3 \times$ wash with PBS-T (PBS+ 0.05\% Tween20), cells were then blocked using 1\% bovine serum albumin (BSA, Sigma-Aldrich, St. Louis, MO, USA) for $30 \mathrm{~min}$ at RT, and incubated with primary mouse anti-human Ki67 antibody (1:100 dilution; clone MIB-1, DAKO, Glostrup, Denmark) in staining buffer (PBS-T $+1 \%$ BSA) overnight at $4{ }^{\circ} \mathrm{C}$. Cells were then washed $3 \times$ with PBS-T, blocked (PBS-T $+1 \%$ BSA $+3 \%$ goat serum) for $15 \mathrm{~min}$, and re-probed with conjugated Alexa-488 goat anti-mouse IgG secondary antibody (1:500 dilution, Invitrogen) for $2 \mathrm{~h}$ at RT. Cells were washed again $3 \times$ with PBS-T, air dried, and mounted with DAPI containing mounting medium (VectaShield, Vector Laboratories Inc, Oxford shire, England). As a negative control, the cells were incubated only with goat anti-mouse Alexa-488 conjugated secondary antibody. Multiple images from different sample replicates were visualized and images were captured using an inverted laser scanning microscope (LSM 510 META; Zeiss, Germany). The Ki67 immunoreactivity was evaluated as the percentage of Ki67-positive cells out of the total population (Adobe Photoshop, San Jose, CA, USA), where at least 500 cells/well were counted. The cells were evaluated from three independent experiments.

\subsection{Cell Death Assay}

To determine the percentage of viable, apoptotic, and necrotic cells following $A \beta_{40 / 42}$ peptide or ACM exposure, treated NGC0211 cells were stained with FITC-Annexin-V (V) and propidium iodide (PI) (Invitrogen) according to the manufacturer's protocol. Briefly, cells $\left(7 \times 10^{4}\right.$ cells /well for $24 / 48 / 72$ h or $3 \times 10^{4}$ cells/well for 7 days) were seeded on 24-well plates (Corning, New York, NY, USA) and left in $500 \mu \mathrm{L}$ of complete medium overnight. Cells were then exposed to $A \beta_{40}$ or $A \beta_{42}$ (final concentrations of $1,0.5,0.1$, $0.05 \mu \mathrm{M}$ ) or ACMs and incubated for respective time points in a total volume of $500 \mu \mathrm{L}$. To have a complete picture of the total cells and the viability, the floating cells were collected after treatment with $\mathrm{A} \beta$-peptides or ACMs and kept separately before the next step. Then, the attached NGC0211 cells were washed $3 \times$ with PBS, trypsinized, and collected by centrifugation $\left(1500 \times g, 4^{\circ} \mathrm{C}, 5 \mathrm{~min}\right)$ and pooled with the floating cells obtained in the previous step (total pool of treated cells = attached + floating) and resuspended in annexin binding buffer. Further, post-exposure supernatant was also separated from floating cells by centrifugation $\left(3000 \times g, 4{ }^{\circ} \mathrm{C}, 5 \mathrm{~min}\right)$ and stored at $-80^{\circ} \mathrm{C}$ for future hmNGF measurements.

Cells were then stained according to the manufacturer's instructions, and data was acquired using a BD-Accuri C6 Plus flow-cytometer (BD Biosciences, Franklin Lakes, NJ, USA). The dual-color analysis allowed the identification of different cell populations: viable 
cells (Annexin $\mathrm{V}^{-} \mathrm{PI}^{-}$), early apoptotic cells $\left(\right.$Annexin $\mathrm{V}^{+} \mathrm{PI}^{-}$), late apoptotic cells (Annexin $\mathrm{V}^{+} \mathrm{PI}^{+}$), and necrotic cells (Annexin $\mathrm{V}^{-} \mathrm{PI}^{+}$).

\subsection{Measurements of hmNGF by ELISA}

The amount of hmNGF levels released by NGC0211 cells, astrocytes, or ECBs after treatment with $\mathrm{A} \beta_{40 / 42}$ peptides or ACMs was measured using a commercial ELISA kit (Cat No. DY256, R\&D Systems, USA; assay range 31.2-2000 pg/mL), with minor modifications as described previously [24]. Briefly, $50 \mu \mathrm{L} /$ well of capture antibody $(2.0 \mu \mathrm{g} / \mathrm{mL}$ in carbonate buffer, $\mathrm{pH}$ 9.8) were plated in a 384-well plate (Nunc Maxisorp, Corning, Gothenburg, Sweden) and incubated overnight. Plates were then washed once for $5 \mathrm{~min}$ with $100 \mu \mathrm{L}$ /well tris-buffered saline, blocked with $100 \mu \mathrm{L} /$ well of $5 \%$ BSA in carbonate buffer for $1 \mathrm{~h}$ at RT, washed $3 \times$ with $100 \mu \mathrm{L}$ /well TBS-T (TBS, 0.05\% Tween 20, 0.01\% $\mathrm{NaN}_{3}$ ), and incubated overnight with $50 \mu \mathrm{L} /$ well supernatant samples or standards at $4{ }^{\circ} \mathrm{C}$. The following day, plates were washed $3 \times$ with $100 \mu \mathrm{L} /$ well TBS-T and incubated with $50 \mu \mathrm{L} /$ well biotinylated detection antibody for $3 \mathrm{~h}$ at RT. Plates were then washed $3 \times$ with $100 \mu \mathrm{L} /$ well TBS-T and incubated with $50 \mu \mathrm{L}$ /well streptavidin-alkaline phosphatase (Streptavidin-AP, 1:10,000 dilution, Roche, Basel, Switzerland) for $1 \mathrm{~h}$ at RT. Finally, plates were washed $2 \times$ with $100 \mu \mathrm{L} /$ well TBS-T followed by one washing with DEA buffer $(1 \mathrm{M}$ Diethanolamine buffer, $\mathrm{pH}$ 9.8). The alkaline phosphatase substrate (p-Nitrophenyl- $\mathrm{Na}_{2}-$ $6 \mathrm{H}_{2} \mathrm{O}, 1 \mathrm{mg} / \mathrm{mL}$ in DEA buffer) was then added $50 \mu \mathrm{L} /$ well and colorimetric data were acquired kinetically in a pate reader (Safire II, Tecan) every $5 \mathrm{~min}$ for $1 \mathrm{~h}$ at $540 \mathrm{~nm}$. Data were analyzed from standard curve plotted in reagent diluent (S1-S10, S1 = $2 \mathrm{ng} / \mathrm{mL}$ ). For direct A $\beta$-treated NGC0211 cells, untreated groups were chosen as the control. When treated with astrocyte-conditioned medium, conditioned medium obtained from untreated astrocytes was set as the control.

\subsection{Human CSF Collection and Cell Exposure}

Human CSF from $\operatorname{AD}(n=17)$, Lewy body dementia (LBD) $(n=14)$, and subjective cognitive impairment (SCI) $(n=19)$ patients were obtained from the GEDOK database and biobank available at Karolinska University hospital memory clinic at Huddinge, Stockholm. These patients were diagnosed based on memory clinic evaluations including clinical examinations, cognitive tests, CSF analysis for $\mathrm{A} \beta$ and tau, and magnetic resonance imaging (MRI). The ethical permission for this study (Dnr: 2015/791-31/4) was obtained from the Regional Ethical Review Board of Stockholm.

NGC0211 cells $\left(2 \times 10^{4}\right.$ cells / well) were plated in 96-well clear bottom black plates and allowed to grow for $24 \mathrm{~h}$ (as described in Section 2.2). The CSF to HE-SFM ratio was previously optimized [21], and the cells were thus treated with $200 \mu \mathrm{L} /$ well, 50:50 mix of human CSF and HE-SFM medium. After $48 \mathrm{~h}$ of exposure, supernatant was collected and replaced with $200 \mu \mathrm{L} /$ well fresh HE-SFM. Following another $4 \mathrm{~h}$ of incubation, $100 \mu \mathrm{L} /$ well supernatant was collected and saved for future hmNGF analysis. In every well, $100 \mu \mathrm{L}$ of HE-SFM media containing $2 \times$ alamarBlue were added and incubated for another $1 \mathrm{~h}$ after which fluorescence was read for alamarBlue as previously described.

\subsection{Statistical Analysis}

Quantitative data are presented as mean \pm standard error of the mean (SEM). Statistical analyses on the in vitro studies were performed by one-way ANOVA with a Tukey's multiple comparison test for comparison of three or more groups or by two-way ANOVA as appropriate, followed by Tukey's multiple comparison test. Statistical analyses were performed using Prism 8 software. Spearman correlation analyses were performed with SPSS software (version 2021). Results with ${ }^{*} p<0.05,{ }^{* *} p<0.01{ }^{* * *} p<0.001$ were considered significant. 


\section{Results}

\subsection{Release of hmNGF Is Altered by Exposure to Human Patient CSF (SCI, LBD, AD)}

To ascertain the effect of human CSF on hmNGF release from NGC0211 cells, we exposed NGC0211 cells to human CSF for $48 \mathrm{~h}(\mathrm{AD}=17, \mathrm{SCI}=19, \mathrm{LBD}=14)$. The ratio between total tau versus $A \beta_{42}\left(t-T a u / A \beta_{42}\right)$ obtained from the CSF data was plotted for disease type segregation (Figure 1A). Exposure of NGC0211 cells to patients' CSF (SCI, $\mathrm{LBD}$, and $\mathrm{AD}$ ) resulted in significant decreases in $\mathrm{hmNGF}$ release when compared to the HE-SFM medium as a control $(p<0.001)$ (Figure 1B). To evaluate whether this effect was due to change in cellular activity or viability, we checked the overall metabolic activity of the cells, which remained unaltered (Figure 1C).

A

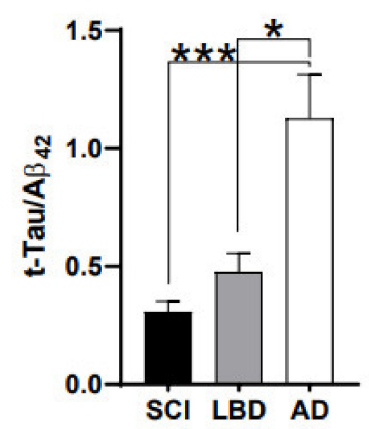

B

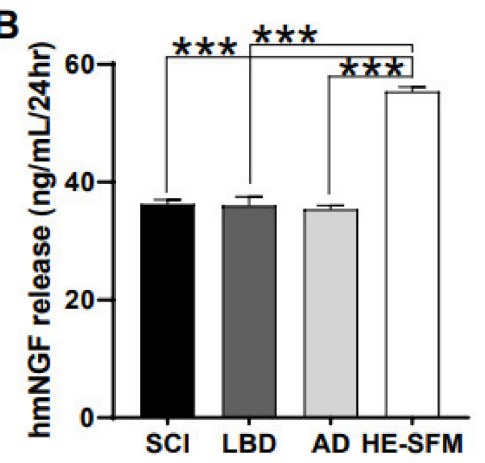

C

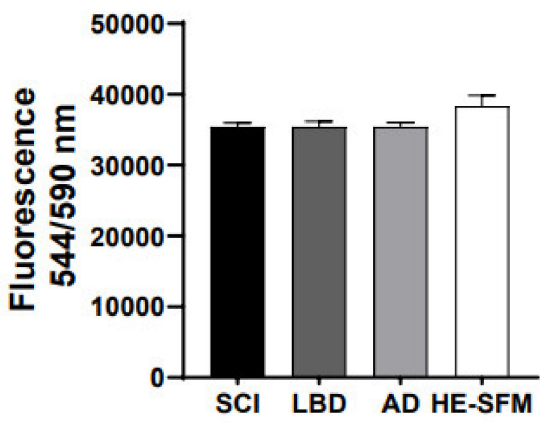

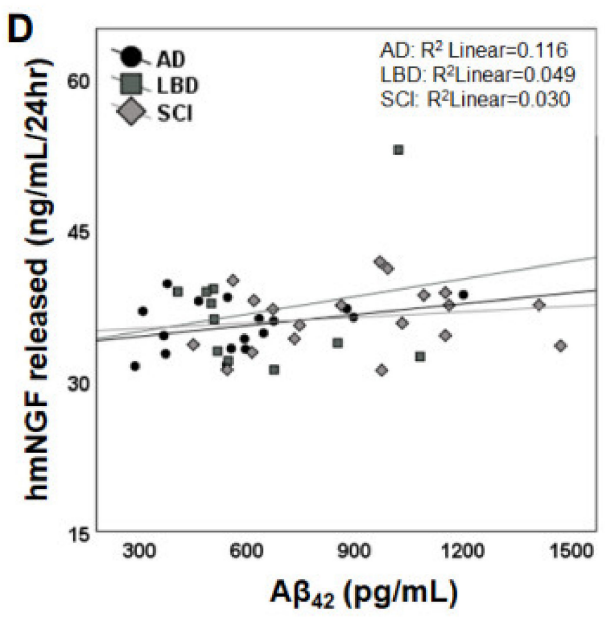
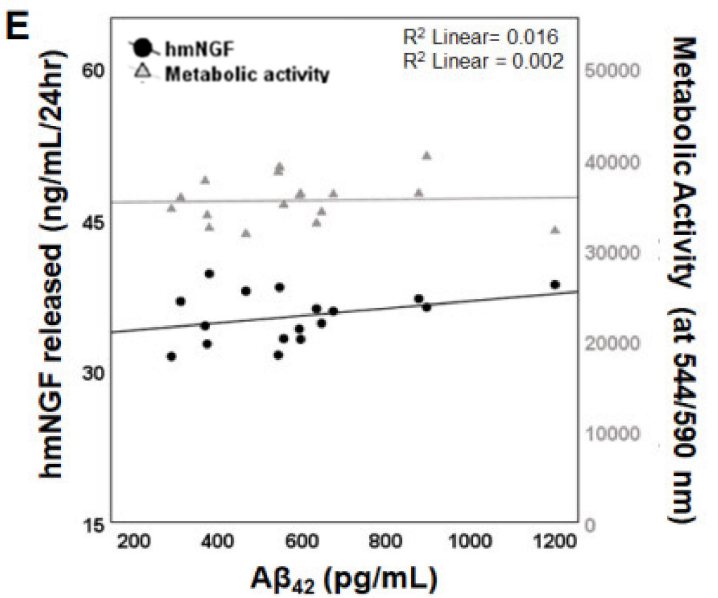

Figure 1. Effect of human CSF on NGC0211 cells. NGC0211 cells $\left(1 \times 10^{4}\right.$ cells/well, 96 -well plate $)$ were cultured in vitro and exposed to human CSF (AD, SCI, LBD) for $48 \mathrm{~h}$ and parameters; hmNGF release and metabolic activity were measured in triplicates. (A) Absolute values of $t-T a u$ and $A \beta_{42}$ levels were obtained from the GEDOK database and plotted as ratios of $\mathrm{t}-\mathrm{Tau} / \mathrm{A} \beta_{42}(\mathrm{AD}=20, \mathrm{SCI}=20, \mathrm{LBD}=11)$ to ascertain pathological segregation of CSF samples. (B) After exposing NGC0211 cells to CSF for $48 \mathrm{~h}(\mathrm{AD}=17, \mathrm{SCI}=19, \mathrm{LBD}=14)$, cells were further incubated with fresh HE-SFM medium (see $\mathrm{M} \& \mathrm{M}$ ) for $4 \mathrm{~h}$ and supernatant was collected to estimate the amount of released hmNGF by ELISA. (C) Using the same experiment (as Figure 1B), after taking out the cell supernatant, adhered cells were incubated with media containing $1 \times$ alamarBlue for $1 \mathrm{~h}$, followed by collection of supernatants to measure alamarBlue fluorescence (544/590 nm). (D) Scatter plots demonstrate the correlation between the release of hmNGF from NGC0211 cells and A $\beta_{42}$ levels in CSF in the samples tested (AD, SCI, LBD). (E) Dual axis scatter plot demonstrating the correlation between the released hmNGF and metabolic activity of NGC0211 cells to the CSF-A $\beta_{42}$ levels, though only within the AD group. Data are represented as mean \pm S.E. Statistical analysis using one-way ANOVA analyses with a Tukey's multiple comparison test was performed to compare control and treated groups in 1A-1C. Spearman correlation analyses was done in $1 \mathrm{D}$ and $1 \mathrm{E} .{ }^{*} p<0.05,{ }^{* * *} p<0.001$. 
To ascertain whether the observed reduction in hmNGF release from NGC0211 cells was due to AD-specific factors, we performed Spearman's correlation between hmNGF release from NGC0211 cells and the $A \beta_{42}$ content of CSF. We observed a non-significant correlation between hmNGF release from NGC0211 cells and CSF A $\beta_{42}$ content (Figure 1D,E), without affecting the metabolic activity of the cells. Nevertheless, since the levels of $A \beta$ in the CSFs were in low nanogram levels (average values: $\mathrm{SCI}=955 \pm 344.043 \mathrm{pg} / \mathrm{mL}$; $\mathrm{LBD}=645 \pm 232.412 \mathrm{pg} / \mathrm{mL} ; \mathrm{AD}=572.444 \pm 234.29 \mathrm{pg} / \mathrm{mL}$ ), which did not affect hmNGF release from NGC0211 cells in vitro (Section 3.2.), the impact of CSFs on hmNGF release from NGC0211 cells may be due to some other factors associated with AD severity, which need further analysis and understanding.

\subsection{Direct Exposure of $A \beta_{40 / 42}$ Peptides Marginally Affected Cell Death, hmNGF Release, and Stress Response}

Flow cytometry analysis demonstrated that $A \beta_{42}$ exerted its toxicity at $24 \mathrm{~h}$, showing higher early apoptotic populations $\left(\mathrm{V}^{+} \mathrm{PI}^{-}\right)(\sim 8 \%)$ than when treated with $\mathrm{A} \beta_{40}(\sim 3 \%)$, and as compared with their respective controls (3.9 and $2.5 \%$, respectively). However, when NGC0211 cells were incubated for 7 days, the species-specific and dose-specific effects on the $\mathrm{V}^{+} \mathrm{PI}^{-}$cell population disappeared (Figure 2A,B). A time-dependent effect of $\mathrm{A} \beta_{40}$ exposure was observed on the accumulation of necrotic cells $\left(\mathrm{V}^{-} \mathrm{PI}^{+}\right.$cells), which was statistically significant after 7 days ( $12 \%$ vs. $6.4 \%$ of control) (Figure $2 \mathrm{C}$ ). This response was not noticed in NGC0211 cells exposed to $\mathrm{A} \beta_{42}(\sim 6 \%$ vs $7.08 \%$ of control) (Figure $2 \mathrm{D})$. Similarly, when late apoptotic cells were assessed $\left(\mathrm{V}^{+} \mathrm{PI}^{+}\right)$, a time-dependent effect was observed for both $\mathrm{A} \beta_{40}$ and $\mathrm{A} \beta_{42}$ peptides (Figure S1A,B). Taken together, these results suggest an early dose-dependent toxicity of $A \beta_{42}$ and a late toxic effect of $A \beta_{40}$ on NGC-0211 cells.
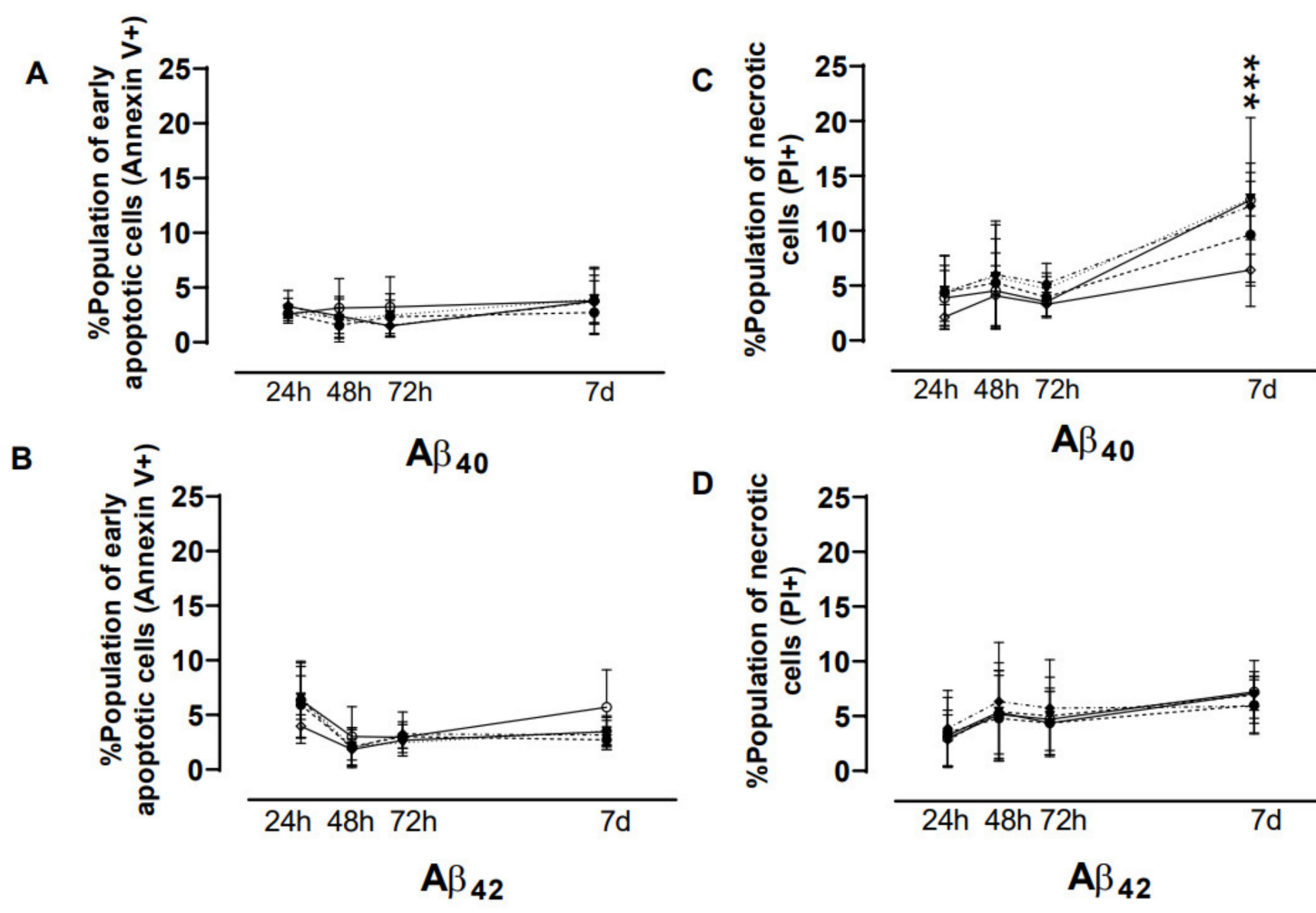

$\mathbf{A} \beta_{40}$

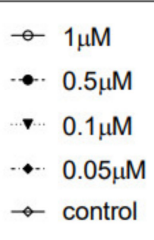

Figure 2. Cont. 
E

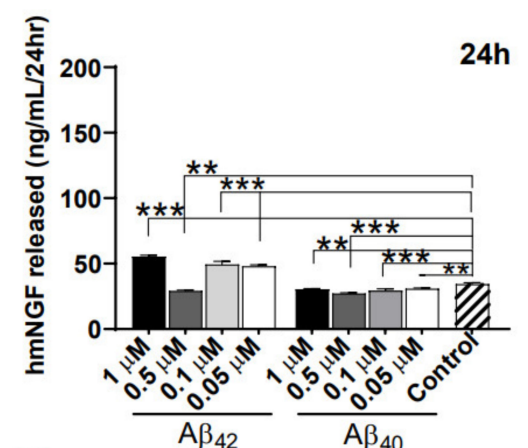

G

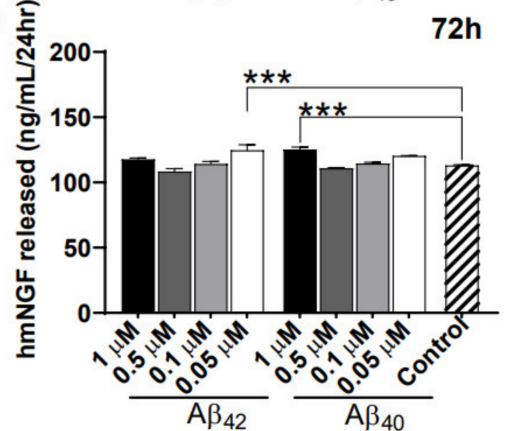

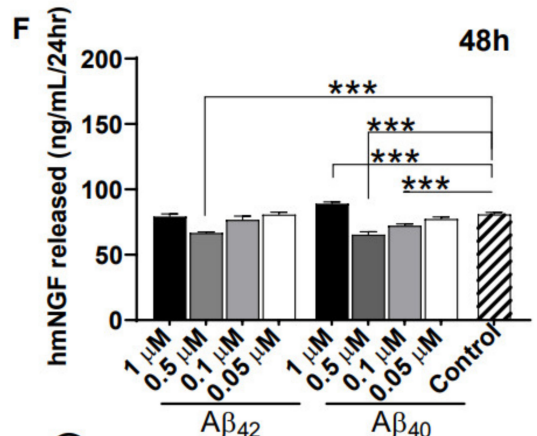

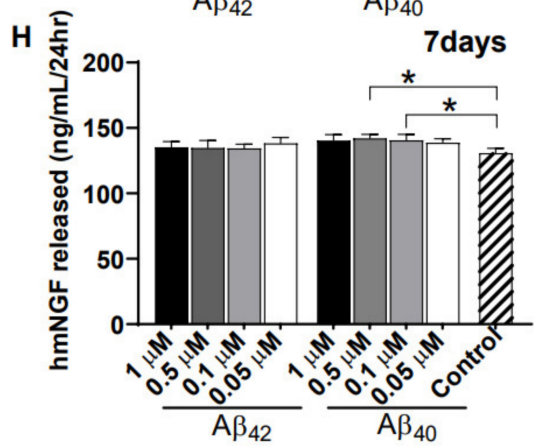

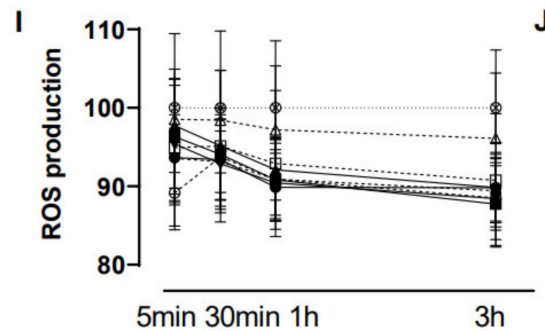
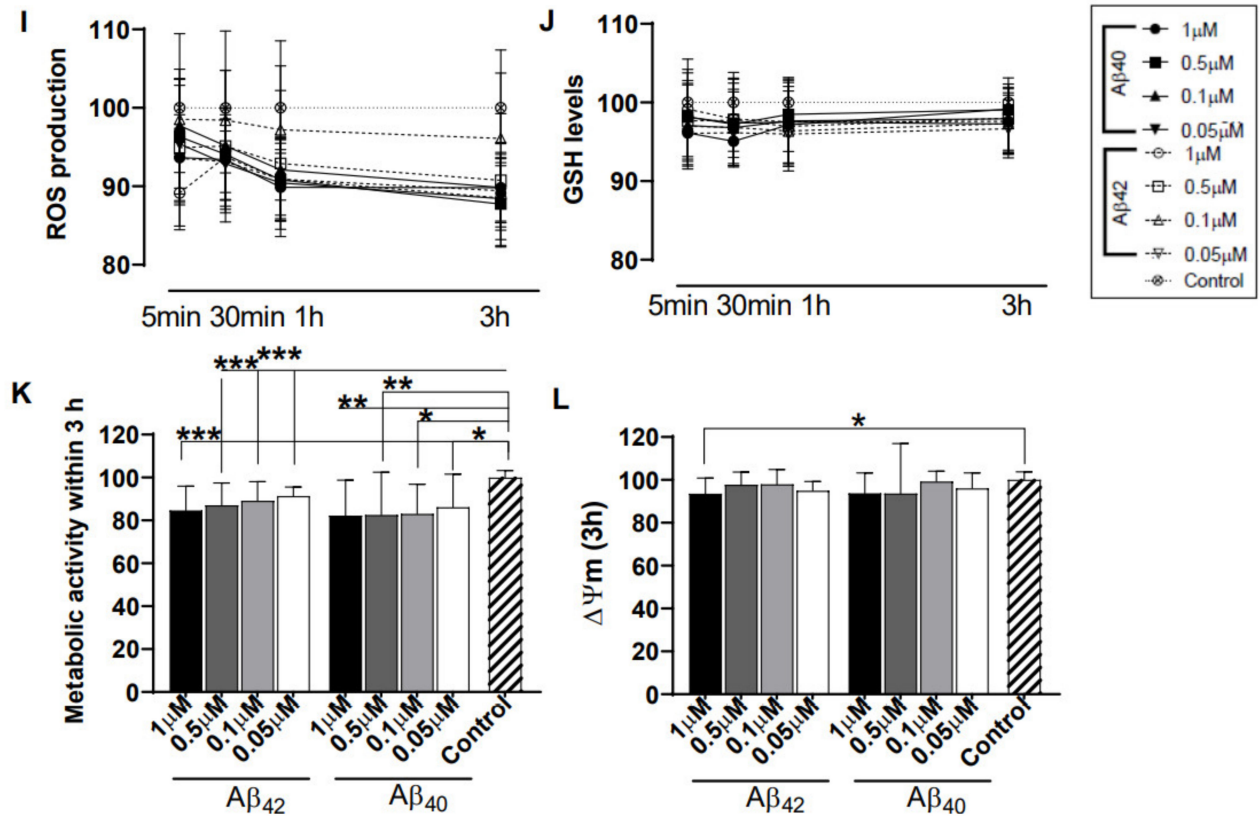

Figure 2. Impact of $\mathrm{A} \beta$ peptides on cell death, hmNGF release, and stress pathways: NGC0211 cells $\left(7 \times 10^{4}\right.$ cells $/$ well for $24 / 48 / 72 \mathrm{~h}$ or $3 \times 10^{4}$ cells/well for 7 days) were seeded on 24 -well plates and incubated with different $\mathrm{A} \beta_{40 / 42}$ concentrations $(1,0.5,0.1,0.05 \mu \mathrm{M})$ for different time points $(24,48,72 \mathrm{~h}$, and 7 days) $(\mathbf{A}-\mathbf{H})$. Supernatant was collected for measurement of hmNGF by ELISA and the cells were further trypsinized and stained with Annexin-V/propidium Iodide (PI) dyes. (A-D) Cells stained with Annexin-V/PI dyes were acquired in a flow cytometer and data is represented as the stained percent population as follows: early apoptotic cell death (Annexin $\mathrm{V}^{+}$), and dead/necrotic cells (Annexin PI ${ }^{+}$). (E-H) The culture supernatant post-A $\beta$ exposure was analyzed for hmNGF content using ELISA and data is represented for different time points. (J-L) NGC0211 cells were treated with various $\mathrm{A} \beta_{40 / 42}$ concentrations $(1,0.5,0.1,0.05 \mu \mathrm{M})$ and evaluated up to $3 \mathrm{~h}$ for ROS production (I), GSH content (J), metabolic activity (K), and mitochondrial membrane potential $(\Delta \Psi \mathrm{m})(\mathbf{L})$ to study the immediate impact on stress-related pathways. Data are represented as mean \pm S.E. $(n=3)$. Statistical analysis using one-way ANOVA analyses with a Tukey's multiple comparison test was performed to compare control and treated groups. ${ }^{*} p<0.05,{ }^{* *} p<0.01$, and ${ }^{* * *} p<0.001$. 
Culture supernatant from the same experiment as above was analyzed for hmNGF release from NGC0211 cells when exposed to A $\beta$ peptides. An overall A $\beta$ species-specific trend was observed at early time points, where $A \beta_{40}$ primarily reduced hmNGF release while $A \beta_{42}$ increased hmNGF release after 24 and $48 \mathrm{~h}$, when compared to their respective controls. However, gradually, $A \beta$ exposure resulted in a mild to significant increase in $\mathrm{hmNGF}$ release at later time points (72 $\mathrm{h}$ and 7 days) when compared to the control group (Figure 2E-H). Interestingly, the $0.5 \mu \mathrm{M}$ concentration of both $\mathrm{A} \beta$ peptides showed reduced hmNGF release at early time points whereas the higher dose of $1 \mu \mathrm{M}$ had the opposite impact, but this difference disappeared with time.

Since cellular stressors (like A $\beta$ peptides) may not induce cell death but can alter the functional properties of the cells, we evaluated various biochemical stress parameters at early $(\leq 3 \mathrm{~h}$ ) or late $(24 \mathrm{~h}$ ) timepoints. At $3 \mathrm{~h}$ (Figure $2 \mathrm{I}, \mathrm{J})$, when compared to their respective controls, $\mathrm{A} \beta_{40 / 42}$ peptide exposure resulted in reduced ROS levels without altering GSH levels. Fluctuations were observed in cellular metabolic activities, where $A \beta_{40}$ caused a significant dose-dependent reduction, whereas $\mathrm{A} \beta_{42}$ exposure was significant with only the highest dose $(1 \mu \mathrm{M}, p<0.05)$ (Figure $2 \mathrm{~K})$. However, mitochondrial activity as measured by membrane potential $(\triangle \Psi \mathrm{m})$ was found to be unaltered (Figure $2 \mathrm{~L}$ ).

We did not observe any significant impact on the stress parameters post $24 \mathrm{~h}$ exposure except that $1 \mu \mathrm{M} \mathrm{A} \beta_{40}$ induced minor changes in $\Delta \Psi \mathrm{m}$ depolarization at $24 \mathrm{~h}$ only $(p<0.05)$, when compared to the respective control (Figure S1C-F). We also evaluated the cellular mitochondrial network as a stress marker [25] (Figure S1G), which showed early disruption by $\mathrm{A} \beta_{40}$ at $24 \mathrm{~h}$ but subsided during the longer exposure time (48/72 $\mathrm{h}$, respectively), especially when using $0.1 \mu \mathrm{M} \mathrm{A} \beta_{40}$. On the other hand, $A \beta_{42}$ peptides seem to have lesser effects at any time point, when compared to $A \beta_{40}$. Overall, our data shows that NGC0211 cells are less affected when exposed to $A \beta$ peptides and can maintain their hmNGF release over a 7-day period.

\subsection{Severe Anti-Proliferative Impact of A $\beta_{40 / 42}$ Peptides on NGC0211 Cells}

To understand whether $A \beta$ peptides affect the NGC0211 cell proliferation rate, we exposed cells to various concentrations of $\mathrm{A} \beta_{40 / 42}(1,0.5,0.1,0.05 \mu \mathrm{M})$, and evaluated Ki67 protein expression (as a marker for proliferation). We observed significantly reduced immunoreactivity for Ki67 indicating hampered proliferation at all time points and doses of $\mathrm{A} \beta$ peptides (Figure 3), when compared to their respective control groups. Although the anti-proliferative impact was similar at $24 \mathrm{~h}$, dose-dependent effects appeared at later time points $(72 \mathrm{~h})$. Among the $A \beta$ peptides, $A \beta_{42}$ showed marginally stronger anti-proliferative effects at all time points when compared to the respective control. Overall, we found that both $\mathrm{A} \beta$ peptides have a severe anti-proliferative effect on NGC0211 cells, and this effect increases time dependently. 

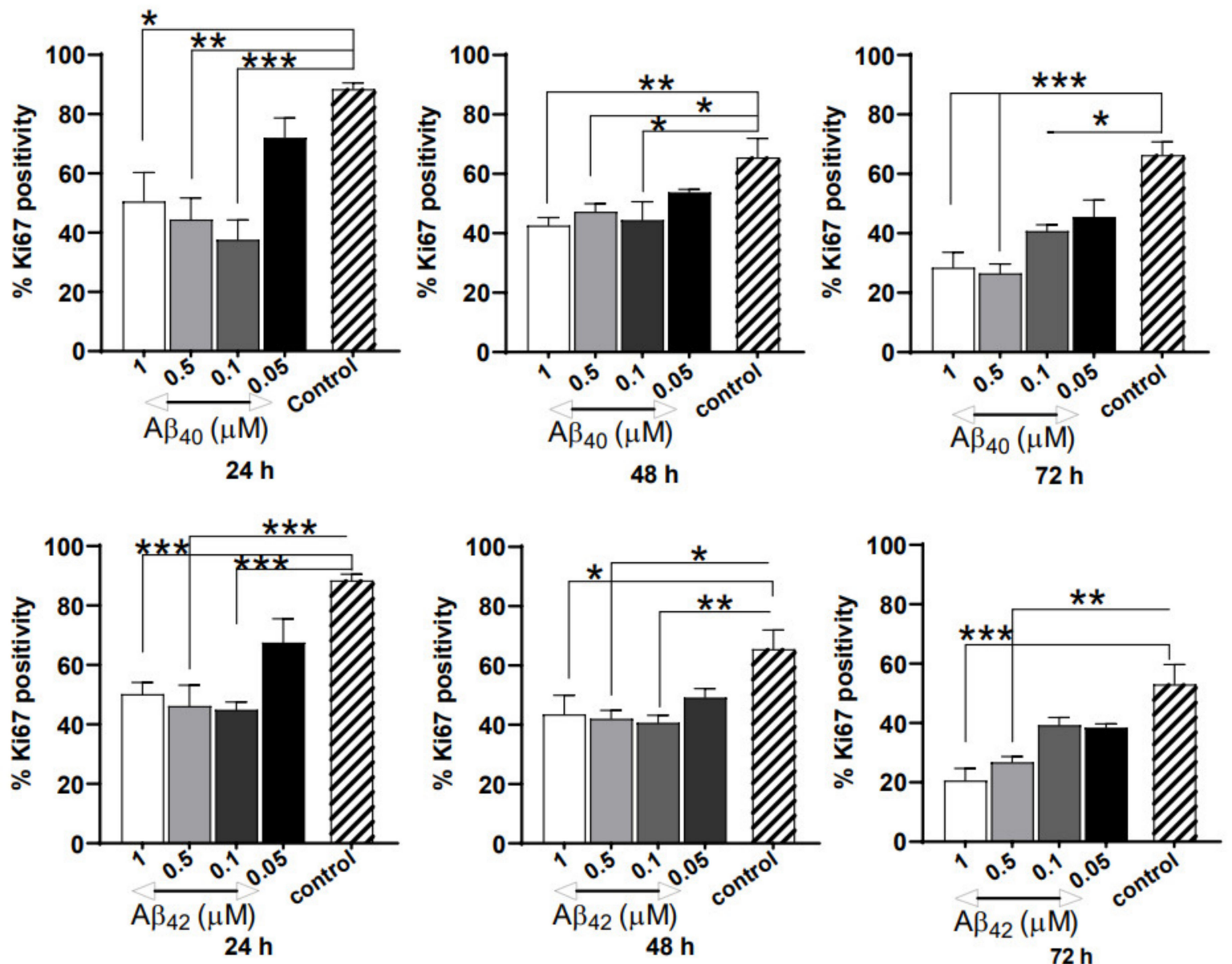

Figure 3. Dysregulation of NGC0211 proliferation by A $\beta$ peptides. To study whether cellular proliferation is affected, NGC0211 cells $\left(0.5 \times 10^{4}\right.$ cells/well) were plated in a 16-well chamber slide and exposed to various $\mathrm{A} \beta_{40 / 42}$ concentrations $(1,0.5,0.1,0.05 \mu \mathrm{M})$ for different time points $(24,48,72 \mathrm{~h})$. Post exposure, cells were fixed and probed with mouse anti-human Ki67 antibody (1:100 dilution; clone MIB-1, DAKO, Glostrup, Denmark) followed by Alexa-488-anti mouse antibody (1:500 dilution, Invitrogen). Slides were mounted and imaged using an inverted laser scanning microscope. At least 3 images from individual samples were counted for Ki67 immunoreactivity and data is presented as Ki67-positive cells taken as a percentage of the total cell population (DAPI staining). Data are represented as mean \pm S.E. $(n=3)$. Statistical analysis using one-way ANOVA analyses with a Tukey's multiple comparison test was performed to compare control and treated groups. ${ }^{*} p<0.05,{ }^{* *} p<0.01$, and ${ }^{* * *} p<0.001$.

\subsection{Astrocyte-Conditioned Media (ACM) Shows Minimal Impact on NGC0211 Cell Death, hmNGF Release, and Stress Response}

Before initiating experiments using human primary cortical astroglial cells, we performed immunostaining with anti-S100 and anti-GFAP to ascertain their purity and activation status of astroglial cells (Figure S2). ACMs derived from A $\beta$-treated astrocytes are denoted as $\mathrm{A} \beta_{40 \mathrm{ACM}}$ and $\mathrm{A} \beta_{42 \mathrm{ACM}}$, respectively. Flowcytometric analysis of NGC0211 cells exposed to ACM for $24 \mathrm{~h}$ showed significant cytoprotective effects from $\mathrm{A} \beta_{40 \mathrm{ACM}}$, whereas low doses of $A \beta_{42 A C M}$ increased cell death, when compared to respective controls (Figure $4 \mathrm{~A}, \mathrm{~B}$ ). To check whether different species of $\mathrm{A} \beta$ differentially activate astrocytes, we performed complement-3 protein analysis from the ACMs but did not observe any difference, when compared to the control group (Figure S3A). 

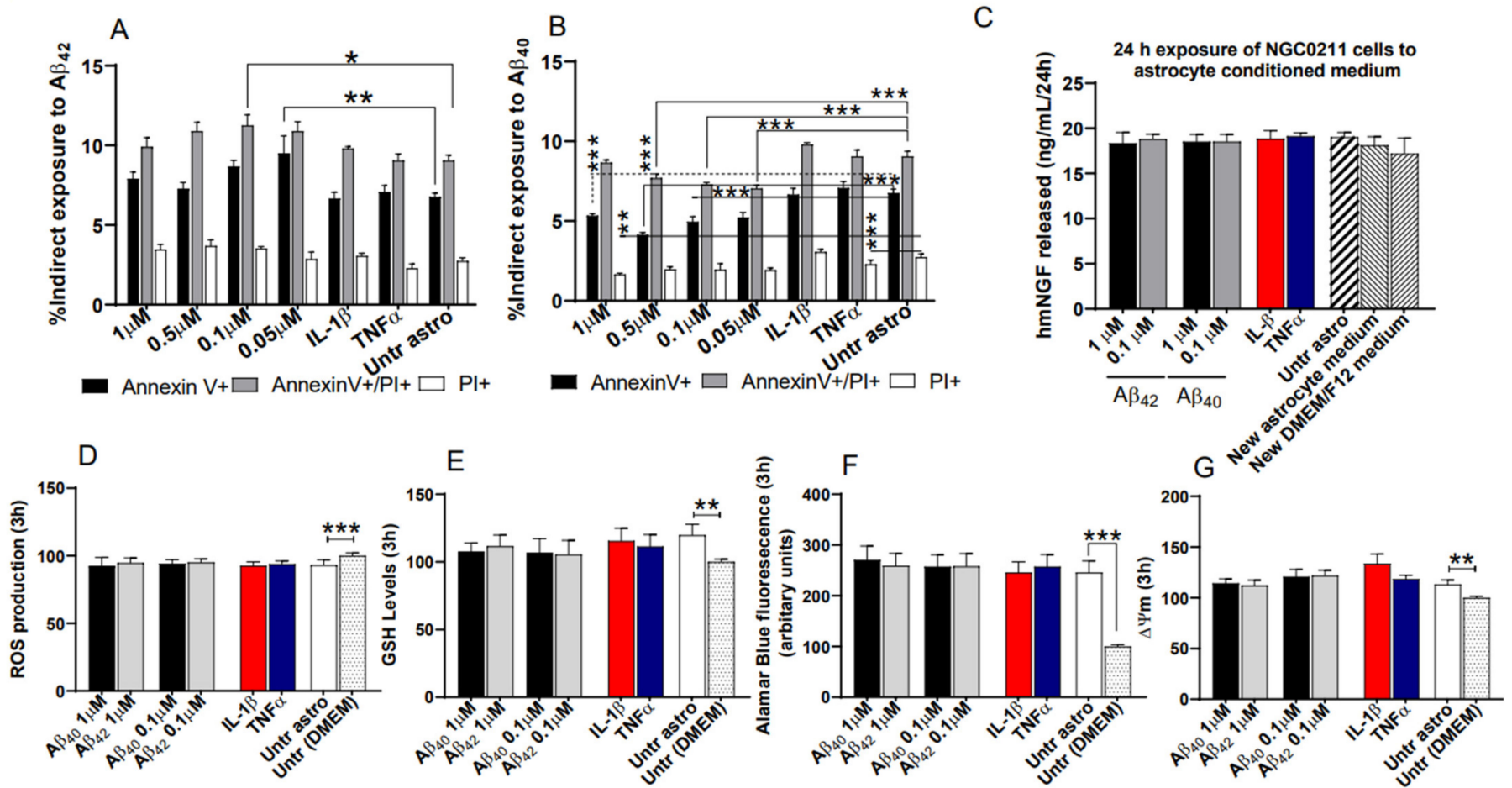

Figure 4. Activated astrocyte-conditioned medium (ACM) modulates NGC0211 cell survival, hmNGF release, and stress pathways. Astrocytes $\left(7 \times 10^{4}\right.$ cells /well) were cultured in 24 -well plates and challenged with $\mathrm{A} \beta_{40 / 42}$ peptides $(1,0.5,0.1$, $0.05 \mu \mathrm{M}$ ), inflammatory molecules (TNF- $\alpha 20 \mathrm{ng} / \mathrm{mL}$, IL-1 $\beta 2 \mathrm{ng} / \mathrm{mL}$ ), or left untreated (control) for 24 h. The astrocyte condition medium (ACM) supernatant was collected, diluted equally with complete DMEM/F12 medium, and used to treat NGC0211 cells for $24 \mathrm{~h}$. (A,B) Treated NGC0211 cells were harvested, stained with Annexin-V/PI dyes, and acquired in a flow cytometer. Data represent the percentage of the stained population as follows: early apoptotic cell death $\left(\right.$ Annexin $\mathrm{V}^{+}$), late apoptotic cell death (Annexin $\mathrm{V}^{+} \mathrm{PI}^{+}$), and dead/necrotic cell (Annexin $\mathrm{V}^{-} \mathrm{PI}^{+}$). Statistical analysis using two-way ANOVA analyses with a Tukey's multiple comparison test was performed. ${ }^{*} p<0.05,{ }^{* *} p<0.01$, and ${ }^{* * *} p<0.001$. (C) Following NGC0211 cell treatment with ACMs for $24 \mathrm{~h}$, the culture supernatant was analyzed for released hmNGF content using ELISA. (D-G) Similarly, after treatment of NGC0211 cells for $3 \mathrm{~h}$ with ACM, cells were probed with different dyes to assess early stress factors like ROS (D), GSH (E), metabolic activity (F), and mitochondrial membrane potential $(\Delta \Psi \mathrm{m})(\mathrm{G})$. Data are represented as mean \pm S.E. $(n=3)$. Statistical analysis using one-way ANOVA analyses with a Tukey's multiple comparison test was performed to compare control and treated groups. ${ }^{*} p<0.05,{ }^{* *} p<0.01$, and ${ }^{* * *} p<0.001$.

Simultaneously, we measured NGF released by the astrocytes after exposure to $\mathrm{A} \beta_{40 / 42}$, IL-1 $\beta$, or TNF $\alpha$ for $24 \mathrm{~h}$, and found differential effects from respective treatments (Figure S3B). However, when NGC0211 cells were treated with $\mathrm{A} \beta_{40 \mathrm{ACM}}, \mathrm{A} \beta_{42 \mathrm{ACM}}$, and IL- $1 \beta / \mathrm{TNF} \alpha_{\mathrm{ACM}}$, no significant effect of ACMs was observed on the hmNGF-releasing ability of NGC0211 cells, when compared to the control group (Figure 4C). To account for the effect of individual media types, astrocyte medium and DMEM/F12, on hmNGF release from NGC0211 cells, we incubated identical wells with fresh media. The addition of fresh astroglial media to NGC0211 cells did not have any significant effect on hmNGF release. To account for the long-term effects of $\mathrm{ACM}$ exposure, treatments (media controls, $\mathrm{A} \beta_{40 \mathrm{ACM}}$, $\left.\mathrm{A} \beta_{42 \mathrm{ACM}}, \mathrm{IL}-1 \beta / \mathrm{TNF} \alpha_{\mathrm{ACM}}\right)$ were replaced with fresh DMEM/F12 and hmNGF release was measured after further incubation for $24 \mathrm{~h}$ (total exposure for every well became $24 \mathrm{~h}+$ $24 \mathrm{~h}$ ). Apart from a significant increase in the IL- $1 \beta_{\text {ACM }}$ group, hmNGF release was not significantly altered in other groups when compared to the untreated astrocyte control group (Figure S3C).

We also measured the effect of ACMs on stress response parameters in NGC0211 cells. ACMs collected from untreated astrocytes showed significant alteration in various biochemical parameters when compared to NGC0211 cells grown in DMEM/F12 media at the 3 (Figure $4 \mathrm{D}-\mathrm{G}$ ) or $24 \mathrm{~h}$ (Figure S4A-D) time points. However, the treated astrocyte 
ACMs $\left(A \beta_{40 A C M}, A \beta_{42 A C M}\right.$, IL-1 $\left.\beta / T N F \alpha_{A C M}\right)$ did not show any significant modulation of biochemical parameters in NGC0211 cells, when compared to untreated astrocytes, which served as an experimental control to observe any treatment-specific changes from astrocytes. All ACMs were found to alter the mitochondrial network after $3 \mathrm{~h}$ of exposure (Figure S4E). These data imply that the cellular factors released by activated astrocytes in ACMs do not induce potential stress in NGC0211 cells, which could significantly alter them functionally, when compared to untreated astrocytes.

\subsection{ACM's Showed Significant Anti-Proliferative Effects on NGC0211 Cells}

To understand whether the positive controls, IL- $1 \beta$ and TNF $\alpha$, had any impact on proliferation, we exposed NGC0211 cells directly to IL-1 $\beta(2 \mathrm{ng} / \mathrm{mL})$ or TNF $\alpha(20 \mathrm{ng} / \mathrm{mL})$ (Figure S5A). As previously observed with direct exposure to $A \beta_{40 / 42}$ peptides, significant anti-proliferative effects were observed from all the treated ACM tested, when compared to respective controls (Figure 5). A $\beta_{40 \mathrm{ACM}}$ showed stronger anti-proliferative effects at 24 and $48 \mathrm{~h}$, but IL- $1 \beta / \mathrm{TNF} \alpha_{\mathrm{ACM}}$ displayed more severe effects on Ki67 expression than A $\beta$ peptides (Figure $\mathrm{S} 5 \mathrm{~B}$ ). The effect of $\mathrm{A} \beta_{40 \mathrm{ACM}}$ and $\mathrm{A} \beta_{42 \mathrm{ACM}}$ showed reduced Ki67 expression in a time-dependent manner until $48 \mathrm{~h}$, after which the effect of $\mathrm{A} \beta_{42 \mathrm{ACM}}$ continued to deteriorate until $72 \mathrm{~h}$, whereas $A \beta_{40 \mathrm{ACM}}$ showed reduced efficacy, when compared to controls. The influence of $A \beta_{40 A C M}$ was dose dependent (except at $48 \mathrm{~h}$ ) whereas $A \beta_{42 A C M}$ showed dose dependency only at $72 \mathrm{~h}$, possibly indicating a long-term effect of $A \beta_{42}$. When the anti-proliferative ability of different ACM was compared, IL-1 $\beta / T N F \alpha_{A C M}$ induced more severe effects on NGC0211, among which $\mathrm{TNF} \alpha_{\mathrm{ACM}}$ displayed a significant long-term suppressive influence. These data show that activated astrocytes have an anti-proliferative effect on NGC0211 cells by reducing Ki67 protein expression.

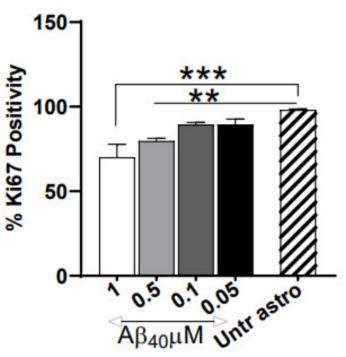

$24 \mathrm{~h}$

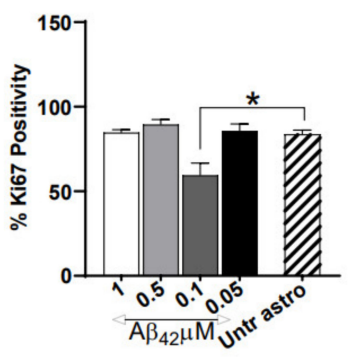

24h

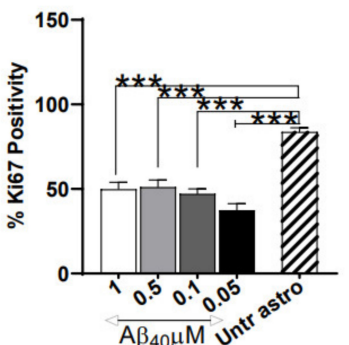

$48 \mathrm{~h}$

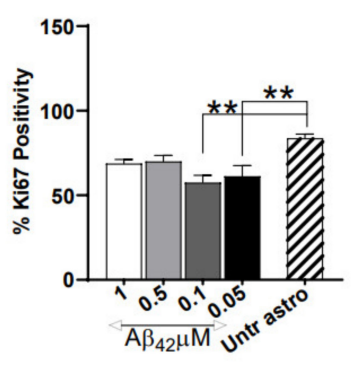

$48 \mathrm{~h}$

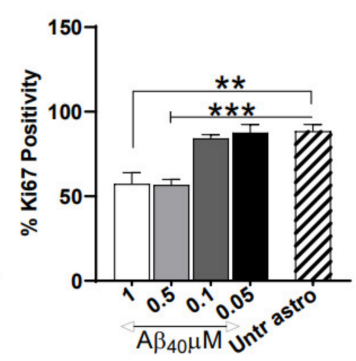

$72 \mathrm{~h}$

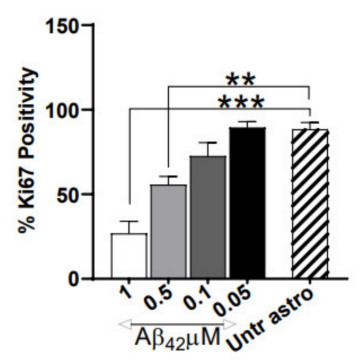

$72 \mathrm{~h}$

Figure 5. ACM displays an anti-proliferative effect on NGC0211 cells. Astrocyte-conditioned medium (ACM) was obtained after treating astrocytes $\left(7 \times 10^{4}\right.$ cells/well, 24 well plates) with $\mathrm{A} \beta_{40 / 42}$ peptides $(1,0.5,0.1,0.05 \mu \mathrm{M})$, inflammatory molecules (TNF $\alpha 20 \mathrm{ng} / \mathrm{mL}$, IL1- $\beta 2 \mathrm{ng} / \mathrm{mL}$ ), or left untreated (control) for $24 \mathrm{~h}$. ACM was used to treat NGC0211 cells (0.5 $\times 10^{4}$ cells/well, 16-well chamber slide) for $24 \mathrm{~h}$. Cells were then fixed, stained with mouse anti-human Ki67 antibody (1:100 dilution; clone MIB-1, DAKO, Denmark) followed by incubation with secondary Alexa-488-conjugated anti-mouse antibody (1:500 dilution, Invitrogen). The slides were mounted using DAPI containing mounting medium. Slides were then imaged, and individually stained cells were counted. Data are represented as mean $\pm \operatorname{S.E}(n=3)$. The quantification of Ki67-positive cells was based on the evaluation of at least 500 cells/well. Statistical analysis using one-way ANOVA analyses and additional Tukey's Multiple Comparison Test was performed to compare control and treated groups. ${ }^{*} p<0.05$, ** $p<0.01$, and ${ }^{* * *} p<0.001$. 


\subsection{Impact of Different Exposure Regimes on the ECB-NGF Device}

Next, we sought to ascertain the effect of $A \beta$ peptides and $A \beta_{A C M}$ on NGC0211 cells growing inside the ECB device. Assessments of metabolic activity and hmNGF release were performed after 7 days of continuous exposure to either $A \beta_{40 / 42}$ peptides directly or to the $\mathrm{ACM}\left(\mathrm{A} \beta_{40 \mathrm{ACM}}, \mathrm{A} \beta_{42 \mathrm{ACM}}\right)$ (Figure 6). We observed differential response from the ECB devices, wherein direct exposure to $A \beta$ peptides reduced hmNGF release whereas exposure to $\mathrm{A} \beta_{40 \mathrm{ACM}}$ and $\mathrm{A} \beta_{42 \mathrm{ACM}}$ significantly increased hmNGF release, as compared to their respective controls (Figure 6A). Upon measurement of metabolic activity from the ECBs, we observed a difference between the exposure types (directly exposed versus ACM-exposed routines), but no alterations were observed when treatments were compared to their respective controls (Figure 6B). The difference in metabolic activity between the different treatment types was not observed in NGC0211 cells under the 2-D-culture setup (Figure 4C), which may indicate a modified response of NGC0211 cells when grown in a 3-D support. We also did not observe any difference when different ECB devices harboring un-transfected ARPE-19, NGC0295, or NGC0211 cells were compared to each other (Figure S6). This data shows that $\mathrm{A} \beta_{40 / 42}$ peptides or the ACM $\left(\mathrm{A} \beta_{40 \mathrm{ACM}}, \mathrm{A} \beta_{42 \mathrm{ACM}}\right)$ did not hamper hmNGF release and metabolic activity of the cells present within the ECB devices, as compared to the respective control groups.

A

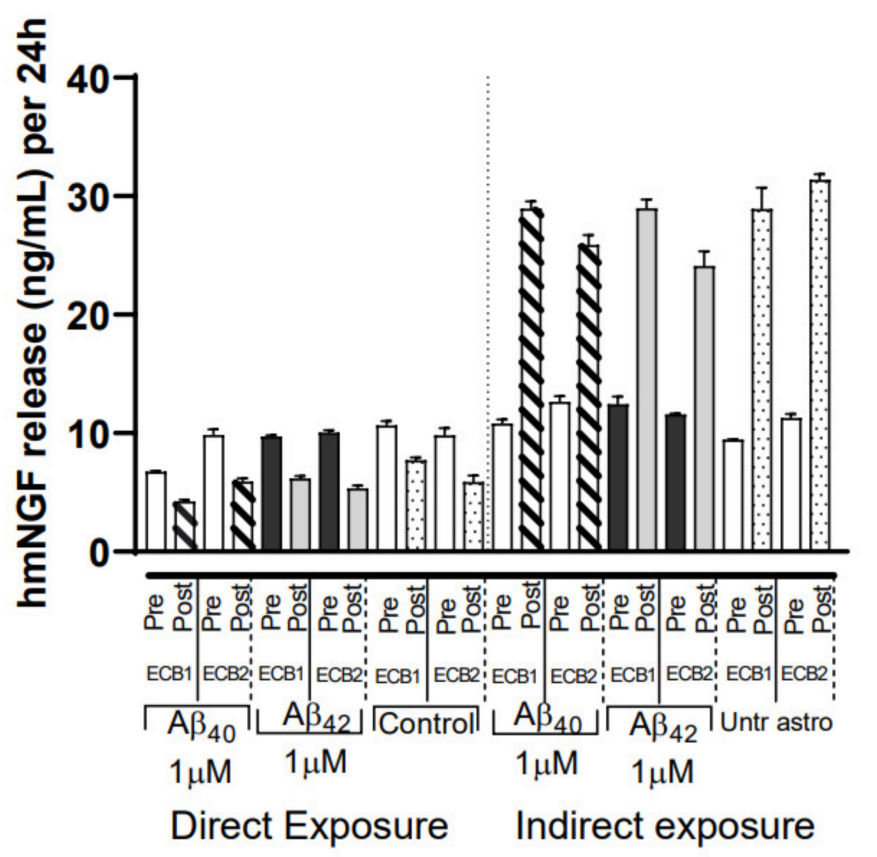

B

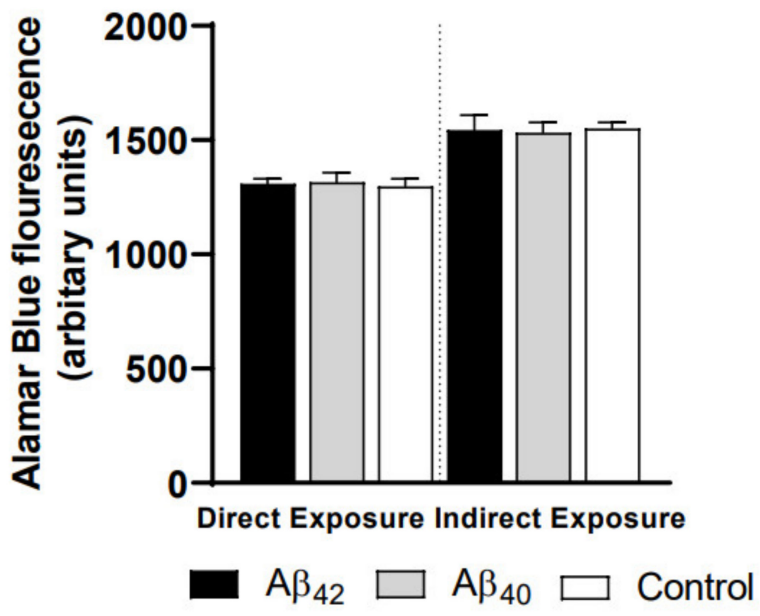

Figure 6. $A \beta_{40 / 42}$ peptides and ACM differentially regulate hmNGF release from ECB devices. ECB devices were maintained in DMEM/F12 media for few weeks before exposing them to $\mathrm{A} \beta_{40 / 42}$ peptides $(1 \mu \mathrm{M})$ or $\mathrm{ACM}$ (treated with $1 \mu \mathrm{M} \mathrm{A} \beta_{40 / 42}$ peptide) for 7 days in a final volume of $1 \mathrm{~mL}$. (A) Following 7 days of exposure, media was replaced with $1 \mathrm{~mL}$ of fresh $\mathrm{DMEM} / \mathrm{F} 12$, and ECB devices were further incubated for $4 \mathrm{~h}$. The amount of hmNGF released during this $4 \mathrm{~h}$ was measured using ELISA (R \& D Systems) by withdrawing $500 \mu \mathrm{L}$ of media. The values obtained were multiplied by a factor of 6 to convert data to hmNGF released over $24 \mathrm{~h}$. Data from individual ECB devices are represented. (B) To measure the impact of the exposure on metabolic activity, $1 \times$ alamarBlue was added and incubated for $1 \mathrm{~h}$. In total, $100 \mu \mathrm{L}$ of medium were drawn in triplicates and fluorescence was measured at 540/590 nm in a Tecan plate reader using a black bottom 96-well plate. Data are represented as mean \pm S.E. $(n=2)$.

\section{Discussion}

This study identified the significant anti-proliferative potential of $A \beta_{40 / 42}$ peptides, inflammatory molecules (TNF $\alpha$, IL-1 $\beta$ ), and activated astrocytes on NGC0211 cells. These mechanisms could be one of the plausible reasons for the unpredictable hmNGF release 
from $E C B$ s over time when implanted in $\mathrm{AD}$ patients $[16,17]$. We also report that $\mathrm{A} \beta_{40 / 42}$ peptides, inflammatory molecules, and activated astroglia do not significantly affect hmNGF release or survival of NGC0211 cells directly. Due to the lack of an effect of these factors on hmNGF release from NGC0211 cells, the acute influence of human CSF on hmNGF release might originate from other proteins not investigated in this study but are present in the diseased condition. Moreover, the effect of CSF is independent of cell death induction and needs further exploration. Conclusions drawn in this study can be attributed to all encapsulated cell-mediated drug delivery strategies since $\mathrm{A} \beta$ peptides and inflammatory molecules are present in high concentrations in the AD brain, whereas inflammation itself is a common part of several pathologies.

In the present study, we used soluble $A \beta$ oligomers since increasing evidence indicates that soluble $A \beta$ oligomers have high pathogenicity [26]. Due to their small size and increased concentration in AD brain tissue (up to $1.3 \mu \mathrm{M}$ ) [27], A $\beta$ peptides can potentially diffuse inside the ECB device and induce NGC0211 cell dysfunction. Similar findings have been previously reported in AMD conditions, where $A \beta$ peptides were shown to affect RPE cells [19]. Moreover, $A \beta$ peptides have been reported to be present in high concentrations in mitochondria [28,29], where they can regulate mitochondrial bio-energetics, leading to ROS generation and hampered mitochondrial activity [30]. Although A $\beta$ peptides are incapable of inducing cell death at a $<5 \mu \mathrm{M}$ concentration [21,31] (Figure 2), they can significantly induce inflammatory responses from ARPE cells, leading to degeneration and accelerated senescence [32,33]. Surprisingly, A $\beta$ peptides were not found to induce oxidative stress in NGC0211 cells, which may be attributed to the antioxidant properties of soluble A $\beta[34,35]$. Nonetheless, we showed that A $\beta$ peptides and inflammatory molecules, such as IL- $1 \beta$ and $\mathrm{TNF} \alpha$, can severely impair NGC0211 cell proliferation when exposed directly (Figure 3, Figure S5B). Our data indicate that NGC0211 cells have the capability to adapt to A $\beta_{40 / 42}$ peptide-induced stress with an extended exposure duration of up to 7 days (Figure S1C-G).

Astrogliosis is also a common pathological feature in $\mathrm{AD}$, where $\mathrm{A} \beta$ peptides themselves are also known to induce astrocytic activation, leading to the release of pro-inflammatory cytokines [36-38]. Astroglia play an important role in RPE cell maintenance, but under pathologically activated conditions, they disturb RPE activity and viability [39]. Specifically, altered inflammatory cytokine expression and increased interleukin-1 receptor antagonist (IL-1ra) expression from human RPE cells have been shown [40]. Previously, we reported the protective response of anti-IL1Ra antibodies on first-generation NGC0295 cells [21]. Our current data shows that based on the hmNGF-releasing capacity and stress response (Figure 4), the second-generation NGC0211 cells are more resistant to IL-1 $\beta$. Our data showed the inability of activated astrocytes to induce redox imbalance, defined as elevated ROS levels with concomitant GSH depletion, but showed effects on mitochondrial activity and connectivity (Figure 4 and Figure S4). A $\beta$ peptides, IL-1 $\beta$, and TNF $\alpha$ induced astrocyte-activation-mediated influence on NGC0211 cell survival, stress response, and hmNGF release, and were also found to be insignificant (Figures 4-6). Although recent evidence shows the involvement of immune cells' effects on encapsulated cells in an in vitro setting [41], the availability and accumulation of these cells might be comparatively less in immune-privileged organs like the brain [42], where glial cells are the major in situ contributors to inflammatory mediators. Nevertheless, due to the role of microglial cells, brain-resident macrophages, in initiating inflammation in the brain tissue, future studies are needed to understand whether microglial cells play a role in hampering encapsulated cells. Similarly, it would be interesting to evaluate the impact of tau and phosphorylated-tau species on NGC0211 cell function due to their increased presence in the brain tissue during the $\mathrm{AD}$ continuum.

Gradual accumulation in dead cells over time (Figure 2C,D) could be due to increased cell death or a gradual dysregulation of dead cell clearance pathways. However, we did not observe a considerable amount of cell death among NGC0211 cells following A $\beta$ or ACM exposure (Figure 2A,B). RPE cells are capable of clearing dead cells by phagocytosis under physiological conditions $[43,44]$, but whether $\mathrm{A} \beta$ peptides or inflammatory molecules can affect RPE phagocytotic activity in vitro is less understood. In the ECB setting, an inability to achieve effective dead cell clearance may lead to a build-up of dead cell bodies, 
which can induce stress [45]. Cell lines grown in ECB devices or culture dishes for a long time (confined space) may develop increased stress, leading to untimely death, and cellular replacement achieved by compensatory proliferation is needed to maintain a steady population of cells [46]. Hampered compensatory replication will lead to subsequent depletion of the overall cell population over time due to an accelerated rate of senescence (and slow proliferation). Our data shows that $\mathrm{A} \beta$ peptides, inflammatory molecules, and astroglial activation have a profound effect on the cell proliferation capacity of NGC0211 cells, suggesting their reduced ability to perform compensatory re-population activities (Figure 3, Figure 5 and Figure S5). This may have a profound influence on the long-term therapeutic application of ECB devices, since over time, depletion of cells may lead to a reduced release of therapeutic molecules. In the present study, hmNGF release data (Figure 2E-H) show that the acute effect of $\mathrm{A} \beta$ disappears with time, perhaps due to the metabolism of $\mathrm{A} \beta$ peptides within the culture set-up, but chronic exposure to $\mathrm{A} \beta$ combined with inflammatory molecules may show different effects.

Apart from a profound impact on NGC0211 cell proliferation, neither $\mathrm{A} \beta_{40 / 42}$ nor ACM were found to affect hmNGF release when cells were grown in conventional 2-D culture (Figure 2, Figure 4 and Figure S3C). Interestingly, significantly higher amounts of hmNGF release were observed when NGC0211 cells growing in 3D support inside ECBs were incubated with $\mathrm{ACM}$ but not with $\mathrm{A} \beta_{40 / 42}$ direct exposure, without altering metabolic activity in any groups (Figure 6). For the direct exposure, a similar reduction of hmNGF release was also observed in the control ECBs, which were not exposed to any treatments, indicating that this response could be a treatment-independent effect. Contrarily, an increase in $\mathrm{hmNGF}$ release after $\mathrm{A} \beta_{\mathrm{ACM}}$ exposure may not be due to the media composition (1:1 ratio; astrocyte: DMEM/F12) since we did not observe such an effect in previous 2-D cell culture experiments (Figure 4C and Figure S3C). The increase may also not be due to factors exclusively released from 'activated' astrocytes since untreated astrocytes (control ECBs) showed a similar hmNGF release when compared to $\mathrm{A} \beta_{\mathrm{ACM}^{-}}$ exposed ECBs. The increased hmNGF release post $A \beta_{\mathrm{ACM}}$ exposure is also independent of $A \beta$ peptides since there is a contrasting observation from the direct $A \beta$ exposure shown in the same figure (direct vs. indirect exposure). One probable factor could be the favorable change in NGC0211 cell behavior when grown in 3-D matrix, which may have enhanced its response to the factors present in the astrocyte-conditioned medium, which enhances hmNGF release or accelerates transgene transcription/translation from NGC0211 cells. We also found that the transfection method utilized did not affect the outcome of these exposures, and the outcome on metabolic activity was similar to the un-transfected ARPE19 when grown in an ECB (Figure S6). These observations under the current experimental conditions may indicate the resilience of the NGC0211 cells towards activated astrocytemediated negative alteration to its hmNGF-releasing capability. Although astrocytes themselves have been reported previously as a major source of NGF [47], these levels do not significantly hamper our study analysis since astrocytic levels are much lower than the levels released from NGC0211 cells or ECB devices (Figure S3). A similar observation was found upon exposing NGC0211 cells to human CSFs, where hmNGF release was significantly reduced (Figure 1B) without considerable alteration of the metabolic activity (Figure 1C). As evident, the AD CSF did not affect metabolic activity in the NGC0211 cells, but a direct correlation was evident between $\mathrm{A} \beta_{42}$ levels and hmNGF release (Figure 1E). Since, in $A D$, the $A \beta_{42}$ content in CSF is gradually decreased as the disease progresses, the data shows that hmNGF release from NGC0211 cells is decreased with increasing severity of AD pathology.

Apart from various other methods of local drug delivery in the brain tissue [14], the ECB platform holds great promise in quantitative and precision drug delivery, which can be safely applied and removed using minimally invasive surgical procedures [15]. Apart from delivering $\mathrm{hmNGF}$, the ECB platform has been successfully tested to deliver various class of proteins in different experimental settings [48-51]. Along with the prevailing inflammatory conditions within the degenerative/damaged brain, ECB implantation procedures may 
result in increased local inflammation due to glial activation and damage to blood vessels and capillaries. Simultaneously, following ECB implantation, it must be bathed with interstitial fluid/CSF within the brain tissue for optimal therapeutic function (outflow of hmNGF) and NGC0211 cell survival (inflow of nutrients and oxygen). Thus, the CSF composition and local presence of activated glia will play an important role in modulating ECB performance post implantation (especially molecules $<280 \mathrm{kDa}$ ). As depicted in Figure 1, hmNGF release from NGC0211 cells was reduced under the influence of AD CSF and was correlated with $A \beta_{42}$ levels. Since $A \beta$ peptides were previously reported to affect RPE survival in AMD [33,52] and induce inflammation from astroglial cells [53,54], we assessed their effect on NGC0211 cell survival under 2-D and 3-D cell culture condition (Figures 2, 4 and 6). Interestingly, we failed to observe any significant influence of these conditions (A $\beta$ exposure and astrocyte-mediated inflammation) on NGC0211 survival and $\mathrm{hmNGF}$ release, indicating that these cells can sustain their functions despite the presence of these stressors. However, the effect of $A \beta$, inflammation, and astroglial activation on cell proliferation will affect the maintenance of cell numbers inside the ECB devices, which eventually may compromise its long-term therapeutic efficacy. Moreover, the identification of pathways that mediate the anti-proliferative impact of $A \beta$, inflammation, and astroglial activation on NGC0211 cells may aid in the production of resistant cells which may advance the therapeutic life term of implanted ECBs.

\section{Limitations}

The major strength of this study is the use of relevant cell culture models, which are directly related to the encapsulated cell therapy targeted previously in AD patients. We also used primary cortical astrocytes from human postmortem brain tissue, thereby trying to recapitulate an appropriate model for astrocyte activation. Another strength of this study is the use of the 2-D and 3-D culture system, showing the differential response of encapsulated cells (NGC0211 cells). A primary limitation of this study is the use of an in vitro cell culture system instead of an animal model, but the reason for performing in vitro culture studies was to understand the specific contribution of $A \beta$ and astrocyte activation towards dysregulation of NGC0211 cells. Animal model studies are often complicated by the fact that several factors are at play in affecting the ECB devices; nevertheless, in vivo studies are the next step to optimize ECB-NGF devices. Another limitation is the observed differential response of NGC0211 cells under the 2-D and 3-D culture set-up, which needs further investigation.

\section{Conclusions}

We showed that NGC0211 cells are physiologically capable of resisting $\mathrm{A} \beta_{40 / 42}$ peptides and astroglial activation-induced stress and continue producing hmNGF in an acute setting. However, we found a significant anti-proliferative impact of $A \beta_{40 / 42}$ peptides, inflammatory molecules, and astroglial activation, which may affect long-term maintenance of the NGC0211 population within the ECB device. Further development of the NGC0211 cells is warranted as a drug delivery vehicle to sustain long-term viability and efficacy in a clinical setting for AD therapy. Several other cell-based therapies have been targeted in $\mathrm{AD}$, and our study may help explain the time-dependent reduction in their efficacy.

Supplementary Materials: The following are available online at https://www.mdpi.com/article/10 .3390 / cells10112834/s1, Figure S1: NGC0211 cells were exposed to A $\beta 40 / 42$ peptides for different time points and various assays were performed, Figure S2: Purity checks of the astrocyte culture, Figure S3: Impact of $A \beta 40 / 42$ peptides on release of complement-C3 and NGF release from astrocytes and hmNGF release from NGC0211 cells, Figure S4: NGC0211 cells were incubated with ACMs and various stress parameters were evaluated, Figure S5: Ki67 immunostaining shows anti-proliferative action of TNF $\alpha$ and IL-1 $\beta$ to NGC0211 cells, Figure S6: Comparison between different cell type carrying ECB devices. 
Author Contributions: Conceptualization (M.E., H.B., S.M., L.U.W., B.L.); Data curation (S.M., H.B., S.T., W.V.O.); Formal analysis (S.M., H.B.); Funding acquisition (M.E., H.B.); Investigation (S.M., S.T., W.V.O.); Methodology (S.M., S.T., W.V.O., H.B.); Project administration (M.E., H.B., B.L., L.U.W.); Resources (M.E., L.U.W., H.B.); Software (M.E., H.B.); Supervision (H.B., S.M., M.E.); Validation (H.B., S.M.); Visualization (S.M., H.B.); Roles/Writing-original draft (S.M.); Writing-review \& editing (S.M., S.T., W.V.O., L.U.W., B.L., H.B., M.E.). All authors have read and agreed to the published version of the manuscript.

Funding: This research was supported by the Swedish research council (2016-02317), Hjärnfonden, Demensfonden, Lindhés stiftelse, Gun and Bertil Stohne's Foundation (20200917), Gamla Tjänarinnor stiftelse (2019-00846), Åhlen stiftelse, Alzheimerfonden, Tore Nilsson stiftelse, KI Geriatric research, KI fund and ALF Foundation for medicine. We want to thank Alzheimer Nederland for financially supporting the International Research Internship of W.V.O., encouraging international collaborations.

Institutional Review Board Statement: Human CSF from AD, LBD and SCI patients were obtained from the GEDOK database and biobank available at Karolinska University hospital memory clinic at Huddinge, Stockholm. The study was conducted according to the guidelines of the Declaration of Helsinki and approved by the Regional Ethical Review Board of Stockholm (2015/791-31/4). Human primary cortical astrocyte cells were procured commercially.

Informed Consent Statement: Not applicable, since samples were obtained from Biobank.

Data Availability Statement: The datasets used and/or analyzed during the current study are available from the corresponding author on reasonable request.

Conflicts of Interest: L.W. is an employee and shareholder of Gloriana Inc. The other authors declare that they have no competing interests.

\section{Abbreviations}

$\begin{array}{ll}\text { AD } & \text { Alzheimer's Disease } \\ \text { SCI } & \text { Subjective cognitive impairment } \\ \text { LBD } & \text { Lewy body dementia } \\ \text { CSF } & \text { Cerebrospinal fluid } \\ \text { A } \beta & \text { Amyloid beta peptide } \\ \text { ECB } & \text { Encapsulated cell biodelivery } \\ \text { NGF } & \text { Nerve Growth Factor } \\ \text { ECB-NGF } & \text { Encapsulated cell biodelivery-NGF device } \\ \text { RPE } & \text { Retinal pigment epithelial } \\ \text { AMD } & \text { Age-related macular degeneration } \\ \text { mNGF } & \text { mature NGF } \\ \text { hmNGF } & \text { human mature NGF } \\ \text { proNGF } & \text { Precursor form of NGF } \\ \text { IL-1 } \beta & \text { Interleukin-1beta } \\ \text { TNF } \alpha & \text { Tumour necrosis factor alpha } \\ \text { BFCN } & \text { Basal forebrain cholinergic neurons } \\ \text { TrkA } & \text { Tropomyosin receptor kinase A } \\ \text { PCR } & \text { Polymerase chain reaction } \\ \text { ACM } & \text { Astrocyte conditioned media } \\ \text { V/PI } & \text { Annexin-V/Propidium Iodide }\end{array}$

\section{References}

1. Cuello, A.C.; Pentz, R.; Hall, H. The brain NGF metabolic pathway in health and in Alzheimer's pathology. Front. Neurosci. 2019, 13, 62. [CrossRef]

2. Teipel, S.J.; Cavedo, E.; Hampel, H.; Grothe, M.J. Basal forebrain volume, but not hippocampal volume, is a predictor of global cognitive decline in patients with Alzheimer's disease treated with cholinesterase inhibitors. Front. Neurol. 2018, 9, 642. [CrossRef] [PubMed]

3. Aloe, L.; Rocco, M.L.; Balzamino, B.O.; Micera, A. Nerve growth factor: A focus on neuroscience and therapy. Curr. Neuropharmacol. 2015, 13, 294-303. [CrossRef] 
4. Cuello, A.C.; Bruno, M.A.; Allard, S.; Leon, W.; Iulita, M.F. Cholinergic involvement in Alzheimer's disease. A link with NGF maturation and degradation. J. Mol. Neurosci. 2010, 40, 230-235. [CrossRef]

5. Peng, S.; Wuu, J.; Mufson, E.J.; Fahnestock, M. Increased proNGF levels in subjects with mild cognitive impairment and mild Alzheimer disease. J. Neuropathol. Exp. Neurol. 2004, 63, 641-649. [CrossRef] [PubMed]

6. Song, W.; Volosin, M.; Cragnolini, A.B.; Hempstead, B.L.; Friedman, W.J. ProNGF induces PTEN via p75NTR to suppress Trk-mediated survival signaling in brain neurons. J. Neurosci. 2010, 30, 15608-15615. [CrossRef] [PubMed]

7. Mufson, E.J.; Li, J.M.; Sobreviela, T.; Kordower, J.H. Decreased trkA gene expression within basal forebrain neurons in Alzheimer's disease. Neuroreport 1996, 8, 25-29. [CrossRef]

8. Boissiere, F.; Hunot, S.; Faucheux, B.; Hersh, L.B.; Agid, Y.; Hirsch, E.C. Trk neurotrophin receptors in cholinergic neurons of patients with Alzheimer's disease. Dement. Geriatr. Cogn. Disord. 1997, 8, 1-8. [CrossRef]

9. Ginsberg, S.D.; Che, S.; Wuu, J.; Counts, S.E.; Mufson, E.J. Down regulation of trk but not p75NTR gene expression in single cholinergic basal forebrain neurons mark the progression of Alzheimer's disease. J. Neurochem. 2006, 97, 475-487. [CrossRef]

10. Sanchez-Ortiz, E.; Yui, D.; Song, D.; Li, Y.; Rubenstein, J.L.; Reichardt, L.F.; Parada, L.F. TrkA gene ablation in basal forebrain results in dysfunction of the cholinergic circuitry. J. Neurosci. 2012, 32, 4065-4079. [CrossRef]

11. Haam, J.; Yakel, J.L. Cholinergic modulation of the hippocampal region and memory function. J. Neurochem. 2017, 142 (Suppl. 2), 111-121. [CrossRef]

12. Ballinger, E.C.; Ananth, M.; Talmage, D.A.; Role, L.W. Basal forebrain cholinergic circuits and signaling in cognition and cognitive decline. Neuron 2016, 91, 1199-1218. [CrossRef]

13. Hasselmo, M.E.; Sarter, M. Modes and models of forebrain cholinergic neuromodulation of cognition. Neuropsychopharmacology 2011, 36, 52-73. [CrossRef] [PubMed]

14. Mitra, S.; Behbahani, H.; Eriksdotter, M. Innovative therapy for Alzheimer's disease-with focus on biodelivery of NGF. Front. Neurosci. 2019, 13, 38. [CrossRef]

15. Wahlberg, L.U.; Lind, G.; Almqvist, P.M.; Kusk, P.; Tornoe, J.; Juliusson, B.; Soderman, M.; Sellden, E.; Seiger, A.; EriksdotterJonhagen, M.; et al. Targeted delivery of nerve growth factor via encapsulated cell biodelivery in Alzheimer disease: A technology platform for restorative neurosurgery. J. Neurosurg. 2012, 117, 340-347. [CrossRef]

16. Eriksdotter-Jonhagen, M.; Linderoth, B.; Lind, G.; Aladellie, L.; Almkvist, O.; Andreasen, N.; Blennow, K.; Bogdanovic, N.; Jelic, V.; Kadir, A.; et al. Encapsulated cell biodelivery of nerve growth factor to the Basal forebrain in patients with Alzheimer's disease. Dement. Geriatr. Cogn. Disord. 2012, 33, 18-28. [CrossRef] [PubMed]

17. Eyjolfsdottir, H.; Eriksdotter, M.; Linderoth, B.; Lind, G.; Juliusson, B.; Kusk, P.; Almkvist, O.; Andreasen, N.; Blennow, K.; Ferreira, D.; et al. Targeted delivery of nerve growth factor to the cholinergic basal forebrain of Alzheimer's disease patients: Application of a second-generation encapsulated cell biodelivery device. Alzheimers Res. Ther. 2016, 8, 30. [CrossRef] [PubMed]

18. Fjord-Larsen, L.; Kusk, P.; Emerich, D.F.; Thanos, C.; Torp, M.; Bintz, B.; Tornoe, J.; Johnsen, A.H.; Wahlberg, L.U. Increased encapsulated cell biodelivery of nerve growth factor in the brain by transposon-mediated gene transfer. Gene. Ther. 2012, 19, 1010-1017. [CrossRef] [PubMed]

19. Kauppinen, A.; Paterno, J.J.; Blasiak, J.; Salminen, A.; Kaarniranta, K. Inflammation and its role in age-related macular degeneration. Cell Mol. Life Sci. 2016, 73, 1765-1786. [CrossRef]

20. Saxena, S.; Maze, M. Impact on the brain of the inflammatory response to surgery. Presse. Med. 2018, 47, e73-e81. [CrossRef]

21. Eriksdotter, M.; Navarro-Oviedo, M.; Mitra, S.; Wahlberg, L.; Linderoth, B.; Tjernberg, L.O.; Behbahani, H. Cerebrospinal fluid from Alzheimer patients affects cell-mediated nerve growth factor production and cell survival in vitro. Exp. Cell Res. 2018, 371, 175-184. [CrossRef]

22. Stine, W.B.; Jungbauer, L.; Yu, C.; LaDu, M.J. Preparing synthetic Abeta in different aggregation states. Methods Mol. Biol. 2011, 670, 13-32. [CrossRef]

23. Wicklund, L.; Leao, R.N.; Stromberg, A.M.; Mousavi, M.; Hovatta, O.; Nordberg, A.; Marutle, A. Beta-amyloid 1-42 oligomers impair function of human embryonic stem cell-derived forebrain cholinergic neurons. PLoS ONE 2010, 5, e15600. [CrossRef] [PubMed]

24. Darreh-Shori, T.; Rezaeianyazdi, S.; Lana, E.; Mitra, S.; Gellerbring, A.; Karami, A.; Bogdanovic, N.; Lithner, C.U.; Winblad, B.; Behbahani, H. Increased active OMI/HTRA2 serine protease displays a positive correlation with cholinergic alterations in the Alzheimer's disease brain. Mol. Neurobiol. 2019, 56, 4601-4619. [CrossRef] [PubMed]

25. Hoitzing, H.; Johnston, I.G.; Jones, N.S. What is the function of mitochondrial networks? A theoretical assessment of hypotheses and proposal for future research. Bioessays 2015, 37, 687-700. [CrossRef] [PubMed]

26. Lai, A.Y.; McLaurin, J. Mechanisms of amyloid-Beta peptide uptake by neurons: The role of lipid rafts and lipid raft-associated proteins. Int. J. Alzheimer's Dis. 2010, 2011, 548380. [CrossRef]

27. Roher, A.E.; Esh, C.L.; Kokjohn, T.A.; Castano, E.M.; Van Vickle, G.D.; Kalback, W.M.; Patton, R.L.; Luehrs, D.C.; Daugs, I.D.; Kuo, Y.M.; et al. Amyloid beta peptides in human plasma and tissues and their significance for Alzheimer's disease. Alzheimer's Dement. 2009, 5, 18-29. [CrossRef]

28. Collins-Praino, L.E.; Francis, Y.I.; Griffith, E.Y.; Wiegman, A.F.; Urbach, J.; Lawton, A.; Honig, L.S.; Cortes, E.; Vonsattel, J.P.; Canoll, P.D.; et al. Soluble amyloid beta levels are elevated in the white matter of Alzheimer's patients, independent of cortical plaque severity. Acta Neuropathol. Commun. 2014, 2, 83. [CrossRef] 
29. Takahashi, R.H.; Nam, E.E.; Edgar, M.; Gouras, G.K. Alzheimer beta-amyloid peptides: Normal and abnormal localization. Histol. Histopathol. 2002, 17, 239-246. [CrossRef]

30. Chen, J.X.; Yan, S.D. Amyloid-beta-induced mitochondrial dysfunction. J. Alzheimer's Dis. 2007, 12, 177-184. [CrossRef] [PubMed]

31. Masuda, N.; Tsujinaka, H.; Hirai, H.; Yamashita, M.; Ueda, T.; Ogata, N. Effects of concentration of amyloid beta (Abeta) on viability of cultured retinal pigment epithelial cells. BMC Ophthalmol. 2019, 19, 70. [CrossRef]

32. Do, K.V.; Kautzmann, M.I.; Jun, B.; Gordon, W.C.; Nshimiyimana, R.; Yang, R.; Petasis, N.A.; Bazan, N.G. Elovanoids counteract oligomeric beta-amyloid-induced gene expression and protect photoreceptors. Proc. Natl. Acad. Sci. USA 2019, 116, 24317-24325. [CrossRef]

33. Liu, R.T.; Gao, J.; Cao, S.; Sandhu, N.; Cui, J.Z.; Chou, C.L.; Fang, E.; Matsubara, J.A. Inflammatory mediators induced by amyloid-beta in the retina and RPE in vivo: Implications for inflammasome activation in age-related macular degeneration. Invest. Ophthalmol. Vis. Sci. 2013, 54, 2225-2237. [CrossRef]

34. Mitra, S.; Prasad, P.; Chakraborty, S. A unified view of assessing the pro-oxidant versus antioxidant nature of amyloid beta conformers. Chembiochem 2018, 19, 2360-2371. [CrossRef] [PubMed]

35. Zou, K.; Gong, J.S.; Yanagisawa, K.; Michikawa, M. A novel function of monomeric amyloid beta-protein serving as an antioxidant molecule against metal-induced oxidative damage. J. Neurosci. 2002, 22, 4833-4841. [CrossRef] [PubMed]

36. Hu, J.; Akama, K.T.; Krafft, G.A.; Chromy, B.A.; Van Eldik, L.J. Amyloid-beta peptide activates cultured astrocytes: Morphological alterations, cytokine induction and nitric oxide release. Brain Res. 1998, 785, 195-206. [CrossRef]

37. Hu, J.; Van Eldik, L.J. Glial-derived proteins activate cultured astrocytes and enhance beta amyloid-induced glial activation. Brain Res. 1999, 842, 46-54. [CrossRef]

38. Lian, H.; Yang, L.; Cole, A.; Sun, L.; Chiang, A.C.; Fowler, S.W.; Shim, D.J.; Rodriguez-Rivera, J.; Taglialatela, G.; Jankowsky, J.L.; et al. NFkappaB-activated astroglial release of complement C3 compromises neuronal morphology and function associated with Alzheimer's disease. Neuron 2015, 85, 101-115. [CrossRef] [PubMed]

39. Vecino, E.; Rodriguez, F.D.; Ruzafa, N.; Pereiro, X.; Sharma, S.C. Glia-neuron interactions in the mammalian retina. Prog. Retin. Eye Res. 2016, 51, 1-40. [CrossRef] [PubMed]

40. Cao, S.; Walker, G.B.; Wang, X.; Cui, J.Z.; Matsubara, J.A. Altered cytokine profiles of human retinal pigment epithelium: Oxidant injury and replicative senescence. Mol. Vis. 2013, 19, 718-728.

41. Li, Y.; Frei, A.W.; Yang, E.Y.; Labrada-Miravet, I.; Sun, C.; Rong, Y.; Samojlik, M.M.; Bayer, A.L.; Stabler, C.L. In vitro platform establishes antigen-specific CD8(+) T cell cytotoxicity to encapsulated cells via indirect antigen recognition. Biomaterials 2020, 256, 120182. [CrossRef] [PubMed]

42. Harris, M.G.; Hulseberg, P.; Ling, C.; Karman, J.; Clarkson, B.D.; Harding, J.S.; Zhang, M.; Sandor, A.; Christensen, K.; Nagy, A.; et al. Immune privilege of the CNS is not the consequence of limited antigen sampling. Sci. Rep. 2014, 4, 4422. [CrossRef] [PubMed]

43. Szatmari-Toth, M.; Kristof, E.; Vereb, Z.; Akhtar, S.; Facsko, A.; Fesus, L.; Kauppinen, A.; Kaarniranta, K.; Petrovski, G. Clearance of autophagy-associated dying retinal pigment epithelial cells-A possible source for inflammation in age-related macular degeneration. Cell Death Dis. 2016, 7, e2367. [CrossRef]

44. Inana, G.; Murat, C.; An, W.; Yao, X.; Harris, I.R.; Cao, J. RPE phagocytic function declines in age-related macular degeneration and is rescued by human umbilical tissue derived cells. J. Transl. Med. 2018, 16, 63. [CrossRef]

45. Ishii, M.; Rohrer, B. Mechanisms of bystander effects in retinal pigment epithelium cell networks. Cell Death Dis. 2017, 8, e3061. [CrossRef] [PubMed]

46. Fan, Y.; Bergmann, A. Apoptosis-induced compensatory proliferation. The Cell is dead. Long live the Cell! Trends Cell Biol. 2008, 18, 467-473. [CrossRef]

47. Goss, J.R.; O’Malley, M.E.; Zou, L.; Styren, S.D.; Kochanek, P.M.; DeKosky, S.T. Astrocytes are the major source of nerve growth factor upregulation following traumatic brain injury in the rat. Exp. Neurol. 1998, 149, 301-309. [CrossRef]

48. Paolone, G.; Falcicchia, C.; Lovisari, F.; Kokaia, M.; Bell, W.J.; Fradet, T.; Barbieri, M.; Wahlberg, L.U.; Emerich, D.F.; Simonato, M. Long-term, targeted delivery of GDNF from encapsulated cells is neuroprotective and reduces seizures in the pilocarpine model of epilepsy. J. Neurosci. 2019, 39, 2144-2156. [CrossRef]

49. Falcicchia, C.; Paolone, G.; Emerich, D.F.; Lovisari, F.; Bell, W.J.; Fradet, T.; Wahlberg, L.U.; Simonato, M. Seizure-suppressant and neuroprotective effects of encapsulated bdnf-producing cells in a rat model of temporal lobe epilepsy. Mol. Ther. Methods Clin. Dev. 2018, 9, 211-224. [CrossRef]

50. Jorgensen, J.R.; Xu, X.J.; Arnold, H.M.; Munro, G.; Hao, J.X.; Pepinsky, B.; Huang, C.; Gong, B.J.; Wiesenfeld-Hallin, Z.; Wahlberg, L.U.; et al. Meteorin reverses hypersensitivity in rat models of neuropathic pain. Exp. Neurol. 2012, 237, $260-266$. [CrossRef]

51. Jorgensen, J.R.; Fransson, A.; Fjord-Larsen, L.; Thompson, L.H.; Houchins, J.P.; Andrade, N.; Torp, M.; Kalkkinen, N.; Andersson, E.; Lindvall, O.; et al. Cometin is a novel neurotrophic factor that promotes neurite outgrowth and neuroblast migration in vitro and supports survival of spiral ganglion neurons in vivo. Exp. Neurol. 2012, 233, 172-181. [CrossRef]

52. Yoshida, T.; Ohno-Matsui, K.; Ichinose, S.; Sato, T.; Iwata, N.; Saido, T.C.; Hisatomi, T.; Mochizuki, M.; Morita, I. The potential role of amyloid beta in the pathogenesis of age-related macular degeneration. J. Clin. Investig. 2005, 115, 2793-2800. [CrossRef] [PubMed] 
53. Gonzalez-Reyes, R.E.; Nava-Mesa, M.O.; Vargas-Sanchez, K.; Ariza-Salamanca, D.; Mora-Munoz, L. Involvement of astrocytes in Alzheimer's disease from a neuroinflammatory and oxidative stress perspective. Front. Mol. Neurosci. 2017, 10, 427. [CrossRef] [PubMed]

54. Wyssenbach, A.; Quintela, T.; Llavero, F.; Zugaza, J.L.; Matute, C.; Alberdi, E. Amyloid beta-induced astrogliosis is mediated by beta1-integrin via NADPH oxidase 2 in Alzheimer's disease. Aging Cell 2016, 15, 1140-1152. [CrossRef] [PubMed] 